\title{
The impact of stimulation treatment on EUR of Upper Devonian formations in the Appalachian Basin
}

Robert R. Krcek

West Virginia University

Follow this and additional works at: https://researchrepository.wvu.edu/etd

\section{Recommended Citation}

Krcek, Robert R., "The impact of stimulation treatment on EUR of Upper Devonian formations in the Appalachian Basin" (2010). Graduate Theses, Dissertations, and Problem Reports. 2103.

https://researchrepository.wvu.edu/etd/2103

This Thesis is protected by copyright and/or related rights. It has been brought to you by the The Research Repository @ WVU with permission from the rights-holder(s). You are free to use this Thesis in any way that is permitted by the copyright and related rights legislation that applies to your use. For other uses you must obtain permission from the rights-holder(s) directly, unless additional rights are indicated by a Creative Commons license in the record and/ or on the work itself. This Thesis has been accepted for inclusion in WVU Graduate Theses, Dissertations, and Problem Reports collection by an authorized administrator of The Research Repository @ WVU. For more information, please contact researchrepository@mail.wvu.edu. 


\title{
THE IMPACT OF STIMULATION TREATMENT ON EUR OF UPPER DEVONIAN FORMATIONS IN THE APPALACHIAN BASIN
}

\author{
Robert H. Krcek
}

\author{
Thesis Submitted to the \\ College of Engineering and Mineral Resources \\ At West Virginia University \\ In Partial Fulfillment of the Requirements \\ for the Degree of \\ Master of Science \\ In \\ Petroleum and Natural Gas Engineering
}

Khashayar Aminian, Ph. D., Chair

Samuel Ameri

Ilkin Bilgesu

Morgantown, West Virginia

2010

Keywords: Appalachian Basin; Benson; Upper Devonian; Stimulation; Production Copyright 2010 Robert H. Krcek 


\title{
WEST VIRGINIA UNIVERSITY
}

\section{ABSTRACT \\ The Impact of Stimulation Treatment on EUR of Upper Devonian Formations in}

\author{
the Appalachian Basin
}

\author{
By Robert H. Krcek \\ Chairperson of the Supervisory Committee: Khashayar Aminian, Ph. D. \\ Department of Petroleum and Natural Gas Engineering
}

This study focuses on how the stimulation treatment design parameters such as the volumes of liquid injected, size and amount of proppant influence the Estimated Ultimate Recovery (EUR), in Upper Devonian formations in the Appalachian Basin. An extensive database containing completion, stimulation, and production data from the Benson formation was compiled and utilized in this study. The selection criteria for wells which were ultimately used in the study included wells with single zone completion and long production history with adequate completion data. These criteria eliminated the major uncertainty caused by multiple zone completions or inconsistent production data. Approximately 95 percent of the wells used in this study had 10 years of production data or more and all of them had completion data including, completion date, type of stimulation job (Water, Nitrogen assist, or Foam Frac), feet of pay (based on $2.55 \mathrm{~g} / \mathrm{cc}$ bulk density), perforated interval, total volume of liquid used during stimulation, total volume of Nitrogen used during stimulation, and total amount of proppant used during stimulation. Only $76 \%$ of the wells had average pump rate during stimulation available. The study found that the variable with the greatest influence on the EUR of the case wells was the total amount of proppant placed during stimulation treatment. Increasing the total proppant not only increases EUR but also decreases the number of wells required to effectively drain the reservoir. Subsequent economic analysis provided the basic guidelines to achieve economic recovery from the Upper Devonian formations in the Appalachian Basin. 


\section{TABLE OF CONTENTS}

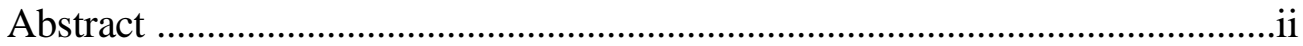

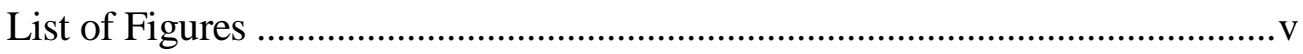

List of Tables ............................................................................................. vii

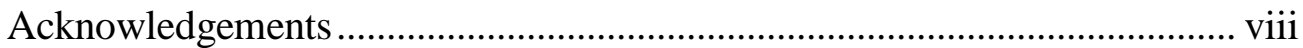

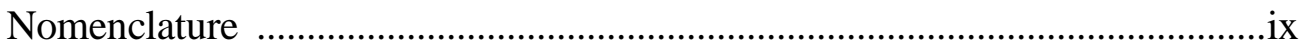

Chapter 1: Introduction..........................................................................................

Chapter 2: Background and Literature Review .....................................................

Geological Overview …………………………………………………...

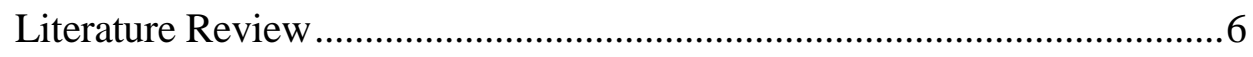

Chapter 3: Methodology ..............................................................................10

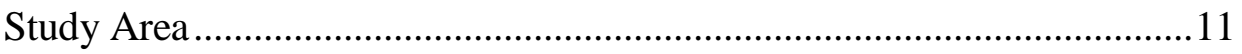

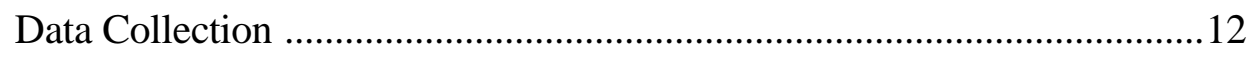

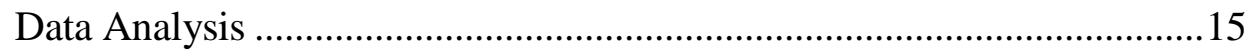

Production History Analysis ....................................................................

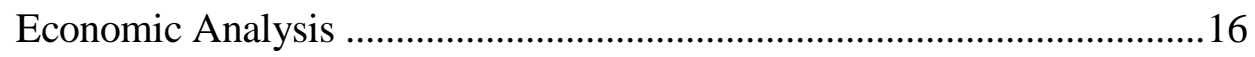

Chapter 4. Results and Discussion................................................................19

Production vs Liquid Volume....................................................................19

Production vs Total Proppant ……………………………….................19

Production History Analysis ....................................................................2

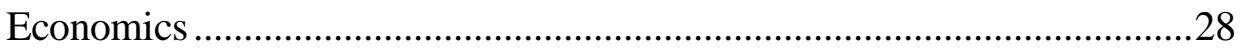


Chapter 5. Conclusion and Recommendation ................................................34

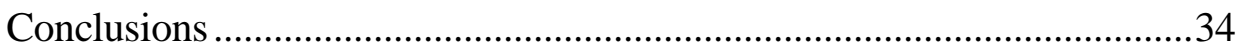

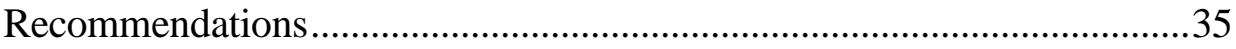

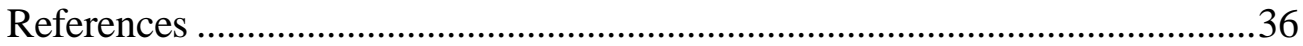

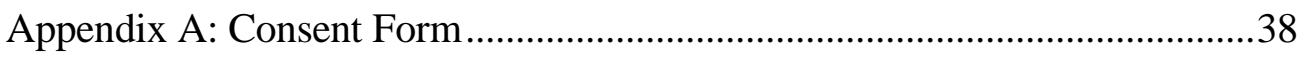

Pocket Material: Maps of Area, Spreadsheets and Graphs 


\section{LIST OF FIGURES}

Number Page

1. Generalized Stratigraghic Column ...................................................5

2. 5 Year Cum vs Total Proppant From 1988 Big Injun Study...........9

3. Active Benson Development Area.....................................................11

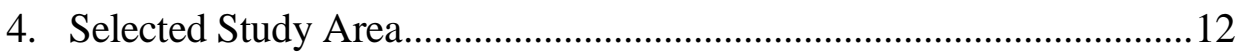

5. Relationship Between EUR and Total Liquid Volume: Area1 ...........20

6. Relationship Between EUR and Total Proppant Placed: Area1 ..........20

7. Relationship Between EUR and Total Proppant Placed: Area2 .........21

8. Relationship Between EUR and Total Proppant Placed: Area3 .........21

9. Relationship Between EUR and Total Proppant Placed: Area4 .........22

10. Relationship Between EUR and Total Proppant Placed: All Areas.....22

11. Relationship Between Liquid Volume and Proppant Placed, Area 1 ..23

12. Reservoir Analysis of Area I: 35,000 Lbs of Proppant Placed ...........24

13. Reservoir Analysis of Area I: 50,000 Lbs of Proppant Placed ...........25

14. Reservoir Analysis of Area I: 78,000 Lbs of Proppant Placed ..........26

15. Production Decline Curve Analysis In Aries......................................29

16. EUR vs Total Proppant Area I Calculated from Trend Line...........30

17. EUR vs Total Proppant Total Area Calculated from Trend Line.....30

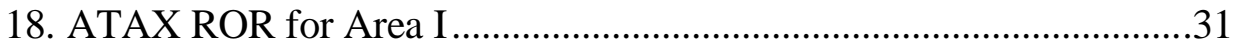

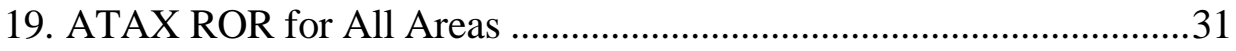


20. Finding and Development Costs for Area I ........................................32

21. Finding and Development Costs for All Areas....................................32 


\section{LIST OF TABLES}

Number

Page

1. Properties from 1988 Big Injun Study........................8

2. Area III Compiled Data for Analysis........................13

3. Well Cost Estimates for Varying Stimulation Sizes...................16

4. Well Cost Breakdown Without Stimulation...................17

5. Stimulation Cost Estimates................................17

6. Table of Results from Reservoir Analysis of Area I..................27

7. Table of Results from Reservoir Analysis of Area I..................28

8. Results Of Economic Analysis for Area I...........................33

9. Results From Economic Analysis for All Areas........................33 


\section{ACKNOWLEDGMENTS}

The author wishes to express sincere appreciation to Dr. Kashy Aminian, Ilken Bilgesu, and Samuel Ameri for offering valuable advice and guidance throughout this program, along with their assistance in the preparation of this manuscript. Also I would like to thank the entire PNGE department for the excellent program they have in place which has greatly help me prepare for my future in the Natural Gas Industry. In addition, special thanks to Ben Hardesty and everyone at Dominion E\&P for their help and assistance and allowing me the time and opportunity to complete this program. Most

importantly, I want to thank my wife, Tania, for her support, confidence, and understanding of all the time put into this adventure. 


\section{NOMENCLATURE}

ATAX ROR. After tax rate of return

b. Hyperbolic exponent of the production decline forecast.

Bbls. Unit of measure, Barrels (42 gallons).

Bcf. Unit of measure, billion cubic feet.

De. Initial decline of the production decline forcast, $(\%)$.

Dmin. Terminal or ending decline of the production decline forecast, $(\%)$.

EUR. Estimated ultimate recovery.

Mcf. Unit of measure, thousand standard cubic feet.

MMcf. Unit of measure, million standard cubic feet.

NYMEX. The New York Mercantile Exchange.

Turbidites. Sea and ocean bottom deposits formed by underwater avalanches.

Upper Devonian. A period of time from 345-395 million years ago.

WVGES. West Virginia Geological and Economic Survey. 


\section{Chapter 1}

\section{INTRODUCTION}

The Upper Devonian play in the Appalachian Basin has potential for additional drilling due to the lack of development and production from the formations below the Venago Group. From my experience, the wells producing from the Bradford and Elk Group, (see Figure 1) have had inconsistent results with production from wells in the same region. Most gas wells which are completed in low permeability formations of the Appalachian Basin, such as the Benson formation, require stimulation to achieve commercial production. Hydraulic fracturing treatments have become a common practice for enhancing the production from the wells of various potential. The ability of a fracture to achieve increased production depends on the size and real extent of fracture. It is often difficult to determine the fracture shape, dimensions, conductivity and the manner the fractures propagate in the subsurface strata due to lack of in-situ rock properties and stress field. As a result, the ability to optimize treatment designs and economics is often limited to selecting the appropriate types of fluids and additives, total volume of fluids, amount and size of the proppant, and injection schedule. ${ }^{1}$

Although the stimulation treatments have enhanced the production from the low permeability formations in the Appalachian Basin, it is uncertain that the treatments

represent the optimum designs. Previous investigations ${ }^{2}$ have revealed that the optimization of treatment designs can further improve economic production. It is therefore necessary to evaluate the impact of the stimulation treatments on EUR and the degree of improvement 
that can be achieved through optimization. More specifically, the objective of this study is to identify the stimulation treatment parameters that had the greatest impact on production and EUR and to place an economic value on them. 


\section{Chapter 2}

\section{BACKGROUND AND LITERATURE REVIEW}

\section{Geological Overview}

The Devonian section of interest contains the strata in the Bradford Play from the base of the Benson to the base of the Warren Shale Marker. The thickness of this package changes across northern West Virginia, being thicker to the east. The entire section is composed of deep water turbidities and shelf deposits of finer-grained sediments. These sediments were transported during the building of the Catskill Delta as a result of the Arcadian Orogeny. ${ }^{3}$ The focus of this study is the Benson Sandstone but a short discussion of the overlying strata is also validated. There are numerous driller's targets and reservoirs in the section of interest including the Benson, Riley, Balltown, and Speechley in order of deposition, (see Figure 1). Because the study area encompasses most of north-central West Virginia, these reservoirs are not always present in all wells and may have slight depositional and lithologic changes. The Benson was first described in the JW Benson (Hope \#3612) well in 1914. ${ }^{4}$ The well was drilled as part of Hope Natural Gas deep drilling program in Barbour County. At that time, most drilling was focused on the Gantz and Fifth Sand. The zone produced $163 \mathrm{Mcfd}$ natural with rock pressures exceeding $1800 \mathrm{psi}$. The Benson Sand/Siltstone is interpreted and mapped as a stacked system of turbidites that were confined into distinct channels. These trends are mapped in the dip direction of ESE to WNW. This is different than the overlying shelf strata, which is typically oriented in the

strike direction. The channels can extend in aerial length up to 30 miles and be as narrow as 
a few thousand feet. The thickness and sand/siltstone percentages are typically higher in the central axis of each channel and decrease towards the channel's limits into the seafloor shales. The higher sand percentages lend themselves to higher porosity and permeability values. It is also important to note that as the Benson thins it also becomes less developed to the west.

The source area for the Benson was located to the eastern Catskill Delta complex fed from the erosion of the Acadian Mountains. ${ }^{5}$ As storms would trigger turbidity currents, sediment would be transported down slope into deeper water. Naturally because of density differences, the heavier sand grains would quickly drop out of water suspension and the finer-grained silts and mud would remain in suspension and travel further offshore. Thicknesses of 15-20 feet are not uncommon in Barbour, Upshur, and Lewis counties. The sand thicknesses in Doddridge County rarely exceed 6 feet and Gilmer County rarely exceeds 4 feet. After lithification, other controls on permeability took effect.

The overlying strata including the Riley, Balltown, and Speechley are all interpreted as shelf deposits. These reservoirs are dominantly oriented in NNE to SSW bands. The Riley is mainly focused in Barbour and Upshur counties where the proximity to the source area has allowed for deposition of thick-stacked coarsening-upward sequences dominated by sand. To the west the Riley is more sporadic and appears in thin lenses of fine-grained sands or siltstones. The Balltown and Speechley reservoirs are also interpreted as shelf deposits. The primary developments of these two pays are located in Harrison and Lewis counties near the crest of the Wolf Summit Anticline. These pays are composed of stacked lenses of fine-grained sandstones. It is not clear how similar these reservoirs are to the Benson Sandstone beyond the grain size. It would be a safe assumption that these reservoirs 
have more in common with the Benson formation than the overlying Venango Sands of the

Fifth Sand and Gordon, which are clean blocky sand bodies. It is anticipated that the stimulation technique advancements made in the Benson will be applicable to the Riley, Balltown and Speechley based on their grain size, lower permeabilities and reservoir pressures.

\begin{tabular}{|c|c|c|c|c|c|}
\hline SYSTEM & SERIES & $\begin{array}{l}\text { GENERAL } \\
\text { LITHOLOGY }\end{array}$ & $\begin{array}{l}\text { AVG. } \\
\text { DEPTH }\end{array}$ & DRILLERS TERMS & GROUP \\
\hline \multirow{4}{*}{ 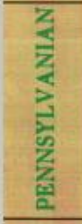 } & \multirow[t]{4}{*}{$\because$} & & 0 & MOUNDSVILLE SANDSTONE & MONONGAHELIA \\
\hline & & \multirow{3}{*}{ 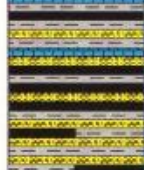 } & & $\begin{array}{l}\text { COW RUN SANDSTONE } \\
\text { DUNKARD SANDSTONE }\end{array}$ & CONEMAUGH \\
\hline & & & 1000 & BURNING SPRINGS SANDSTONE & ALLEGHENY \\
\hline & & & & SALT SANDS & POTTSVILLE \\
\hline \multirow{3}{*}{$\begin{array}{l}\frac{3}{c} \\
\frac{2}{\bar{E}} \\
\frac{2}{5} \\
\frac{2}{2} \\
\end{array}$} & UPPER & & & 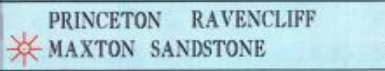 & MAUCH CHUNK \\
\hline & MIDDL素 & & & \& BIG LIME & GREENBRIER \\
\hline & LOWER & $=$ & 2000 & $\begin{array}{l}\text { tै - WEIR SANDSTONE } \\
\text { क्र - BEREA SANDSTONE } \\
\text { MURRYSVILLE SANDSTONE }\end{array}$ & POCONO \\
\hline \multirow{7}{*}{ A) } & \multirow{4}{*}{ 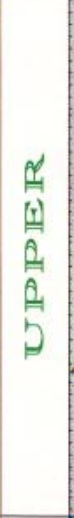 } & \multirow{4}{*}{ 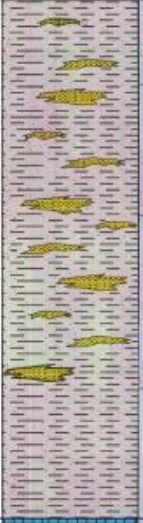 } & \multirow{2}{*}{ 直 } & $\begin{array}{l}\text { FIFTH SANDSTONE } \\
\text { BAYARD SANDSTONE }\end{array}$ & VENANGO \\
\hline & & & & $\begin{array}{l}\text { SPEECHLEY SANDSTONE } \\
\text { BALLTOWN SANDSTONE } \\
\text { - } \begin{array}{l}\text { B } \text { BRADFORD SANDSTONE } \\
\text { KANE SANDSTONE }\end{array}\end{array}$ & BRADFORD \\
\hline & & & 直 & $\begin{array}{l}\text { *ै-BENSON SANDSTONE } \\
\text { ALEXANDER SANDSTONE } \\
\text { ैㅏ-ELK SANDSTONE }\end{array}$ & ELK \\
\hline & & & & & \\
\hline & \multirow[t]{2}{*}{ 뜰 } & 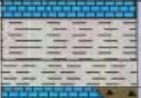 & 8000 & $\begin{array}{l}\text { TULLY LIMESTONE } \\
\text { HAMILTON SHALB } \\
\text { MARCELLUS SHALE }\end{array}$ & \\
\hline & & & & 斻 ONONDAGA LS. HUNTERSVILLE & ONONDAGA \\
\hline & 略 & & & $\begin{array}{l}\not \ngtr-\text { ORISKANY SANDSTONE } \\
\not \ngtr-\text { HELDERBERG LIMESTONE }\end{array}$ & ORISKANY \\
\hline
\end{tabular}

Figure 1 Generalized Stratigraphic Column 


\section{LITERATURE REVIEW}

Hydraulic fracturing is performed in thousands of wells each year in the United States to increase the production of oil and gas from these wells. Stimulation of oil and gas wells was first used in the United States in $1947^{6}$ and is very critical to the production of oil and gas. The United States has an abundant supply of natural gas and it is estimated that $80 \%$ of the natural gas wells drilling over the next decade in the US will need hydraulic fracturing to be commercially economic.

Hydraulic fracturing is a very complicated and technical process but can be simplified by this description from Wikipedia: When applied to stimulation of oil/gas wells, the objective of hydraulic fracturing is to increase the amount of exposure a well has to the surrounding formation and to provide a conductive channel through which the fluid can flow easily to the well. A hydraulic fracture is formed by pumping a fracturing fluid into the well bore at a rate sufficient to increase the pressure down hole to a value in excess of the fracture gradient of the formation rock. The pressure then causes the formation to crack which allows the fracturing fluid to enter and extend the crack further into the formation. In order to keep this fracture open after the injection stops, a solid proppant is added to the fracture fluid. The proppant, which is commonly a sieved round sand, is carried into the fracture. This sand is chosen to be higher in permeability than the surrounding formation and the propped hydraulic fracture then becomes a high permeability conduit through which the formation fluids can be produced back to the well. 
Since 1947, there has been significant research done and papers written on hydraulic fracturing and the impact it has on production. In the Piceance Basin, in the Williams Fork formation, it was found that increasing the stimulation job size also increased production. The Williams Fork formation is a fluvial sandstone formation where most areas are heavily fracture and over pressured. Gross thickness can exceed 3000 feet and permeabilities are in the range of 0.05-0.50 md. David D. Cramer ${ }^{7}$ stated that "post-frac well performance in unconventional reservoirs correlates more strongly and directly with fluid volume than with proppant volume. In Williams Fork completions in the Piceance Basin, several operators have improved well productivity by doubling fluid volume and maintaining the same proppant volume by cutting the proppant concentration in half." The completions in the Piceance Basin did not indicate the volumes of stimulation fluid or proppant used. It is possible the volume of proppant used was adequate to prop the fracture network and by doubling the fluid volume during stimulation the fracture volume was also increased creating greater contact with the reservoir.

In tight gas sandstone reservoirs there has been research indicating the importance of conductivity and how the created fracture needs to be propped after stimulation. N.R. Warpinski discussed the results from a flow test capacity on fractures between split core form the Cotton Valley sandstone formation that evaluated unpropped and partially propped fractures. The Cotton Valley sandstone formation is a fluvial sandstone deposit with gross thickness that can exceed 3000 feet, it is classified as a tight gas sand. It was found that unpropped fractures from split core retain some conductivity at low stress. However, at stress above 3,000 psi, these fractures were observed to heal and provide 
essentially zero flow capacity. ${ }^{8}$ From this test data it indicates that if a fracture network is created during stimulation of the formations and a propping agent is not placed adequately throughout the fracture, then gas production gains due to more injection fluid used during stimulation could be short term.

In West Virginia, research has been done on the optimization of hydraulic fracturing in the Big Injun formation. The Big Injun formation is a fluvial-deltaic sandstone with gross thickness usually in the 20-50 feet range. It is considered a tight gas sandstone and requires hydraulic fracturing to be an economic play. Research that was done by K. Aminian ${ }^{9}$ in 1988 on the Big Injun formation was investigated. The information that was gathered from his research was a group of eight wells with a minimum of ten years of production and the stimulation parameters used during completion. See Table 1. For compiled data from the Big Injun study in 1988.

\begin{tabular}{|c|c|c|c|c|c|c|c|c|}
\hline Well & Net Pay & $\mathbf{5}$ year Cum & $\mathbf{1 0}$ Year Cum & Liq. Vol. & Avg Rate & Total Prop & Avg Prop. Conc. & Prop/Ft \\
\hline 1 & 14 & 90.5 & 126 & 22600 & 53.8 & 45700 & 2.022123894 & 3264.285714 \\
\hline 2 & 10 & 84.5 & 116.3 & 23500 & 51.8 & 46000 & 1.957446809 & 4600 \\
\hline 3 & 10 & 199.2 & 287.8 & 33700 & 49.8 & 52200 & 1.548961424 & 5220 \\
\hline 4 & 16 & 97.8 & 162.5 & 35500 & 44.8 & 49700 & 1.4 & 3106.25 \\
\hline 7 & 12 & 63.9 & 103.8 & 30200 & 37 & 40600 & 1.344370861 & 3383.333333 \\
\hline 8 & 12 & 166.9 & 229.6 & 38900 & 46.4 & 51900 & 1.334190231 & 4325 \\
\hline \multicolumn{8}{|c|}{ Removed Data } \\
\hline 5 & 9 & 76.6 & 120.1 & 34300 & 51.4 & 57200 & 1.667638484 & 6355.555556 \\
\hline 6 & 18 & 243 & 337.3 & 26700 & 49.6 & 41600 & 1.558052434 & 2311.111111 \\
\hline
\end{tabular}

Table 1. Properties from 1988 Big Injun Study

When the data was plotted and investigated for correlation between production and stimulation parameters using all data, no strong correlation were found. What was noticed 
is that two data points (Wells 5 and 6), appeared to be outliers on all the graphs. One well had the thinnest net pay and the other had the thickest net pay, also some of the data appeared to be skeptical, such as porosity and permeability. Well 6 had $430 \%$ greater permeability than the average of all the other wells. With wells 5 and 6 removed from the graphs the best correlation that was found between production and stimulation parameters was with Total Proppant used, see Figure 2.

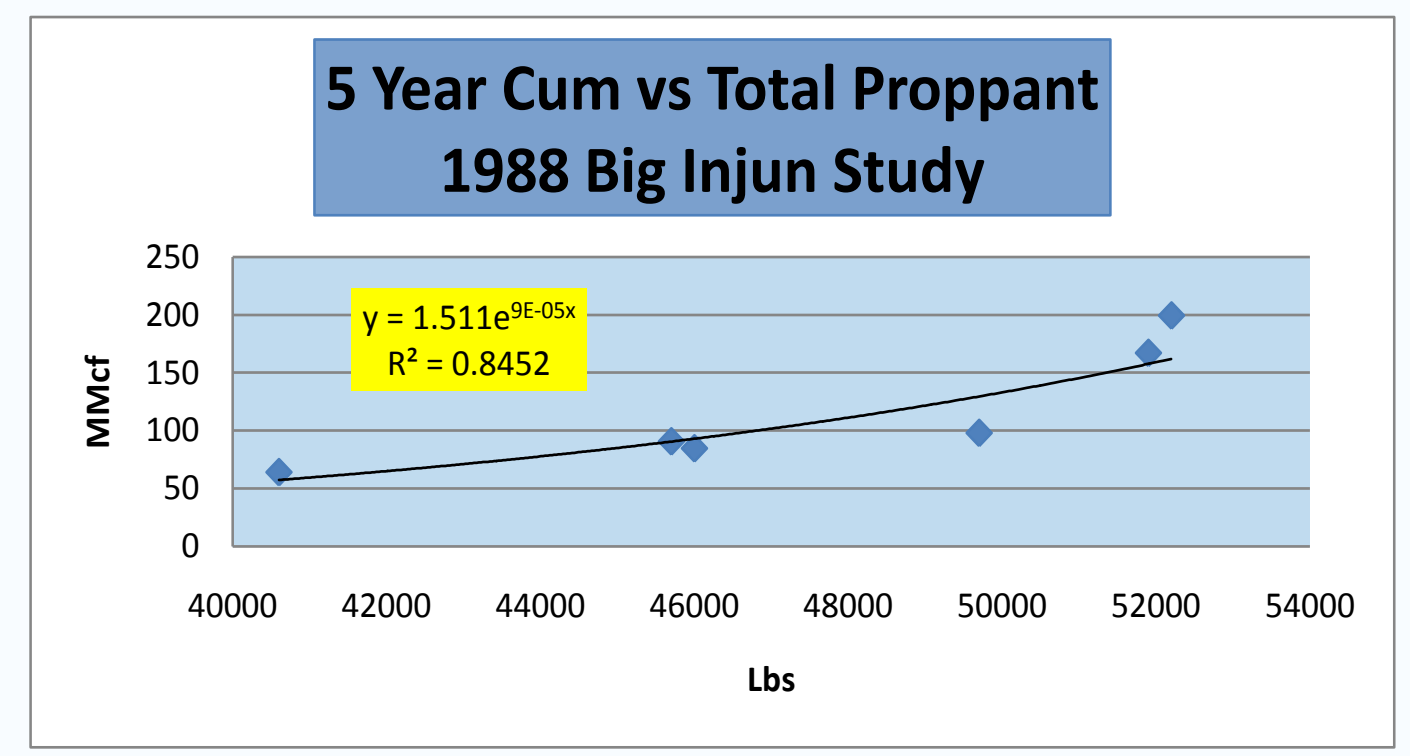

Figure 2. 5 Year Cum vs Total Proppant

From Figure 2. a strong correlation between production and total proppant can be made at around an $85 \%$ confidence level. When 10 year cumulative production was used almost identical results were found. 


\section{Chapter 3}

\section{METHODOLOGY}

To describe the methodology used in this study a list of steps or outline was followed throughout the research:

1. Define Problem Statement: How the stimulation treatment parameters effect the production or EUR of the Upper Devonian formations in the Appalachian basin.

2. Study Area: Find a study area that contains a sufficient number of wells with the formation of interest.

3. Data Collection: Collect all relevant data pertaining to production, completion, formation, and stimulation.

4. Data Analysis: With all data collected in Excel spreadsheets, plots were made between production and all stimulation parameters to find best correlations.

5 Production History Analysis: Aries was primarily used to find the decline curve parameter which were used for the economic portion of the study. Fekete was also used to verify EURs and investigate permeability, skin, and drainage area

6. Economic Analysis: All economic analysis was based on results from data analysis and production history analysis and performed using Aries software. 


\section{STUDY AREA}

Most wells that produce from the Upper Devonian section in the Appalachian Basin have multi-zone completion and comingled production. As a result, it is difficult to find a good study group. When looking for a study area and well sample group, it was found the Benson sand/siltstone formation is often completed as a single zone. The focus of this study is the Benson Sandstone which is productive in North Central West Virginia as illustrated in Figure 3. Dominion E\&P has over 3500 wells completed in the Benson formation, out of which it was possible to identify 500+ wells that were completed only in Benson. To keep reservoir properties more consistent, four groups of wells were selected namely Area I, Area II, Area III and Area IV as illustrated in Figure 4.

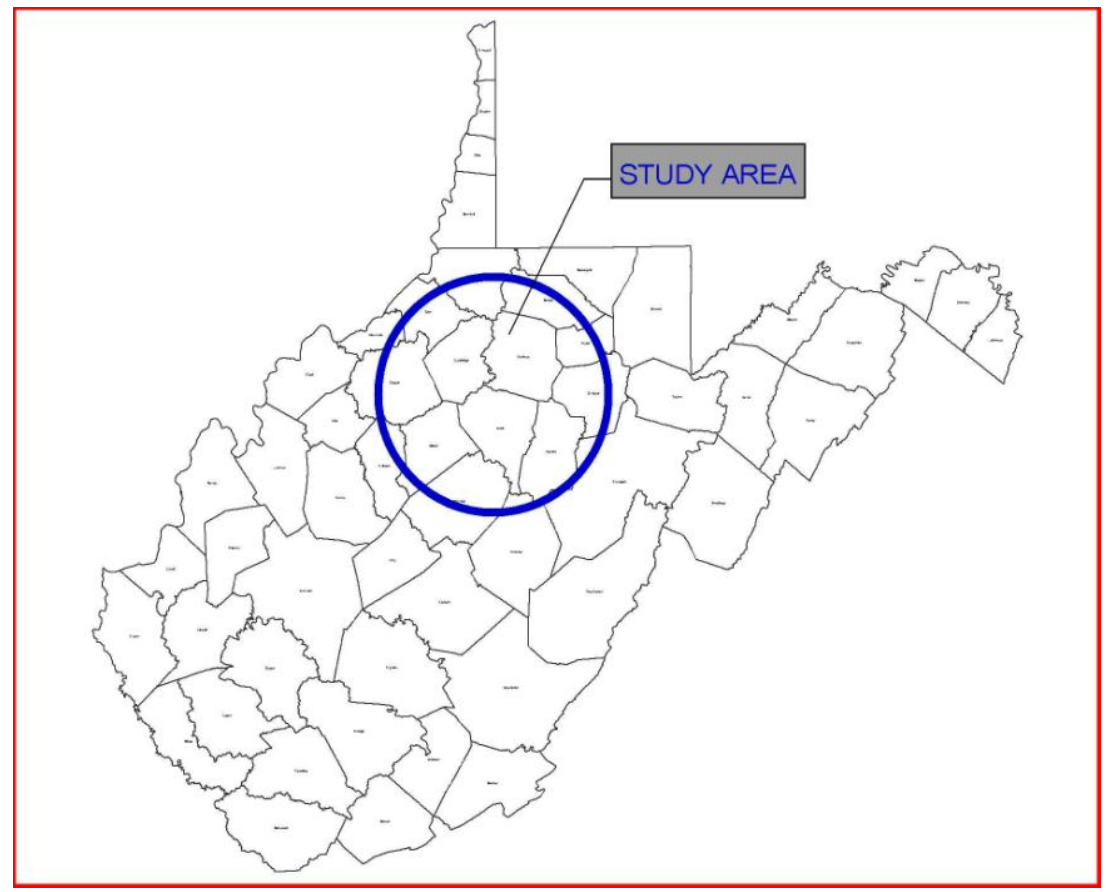

Figure 3. Active Benson Development Area 


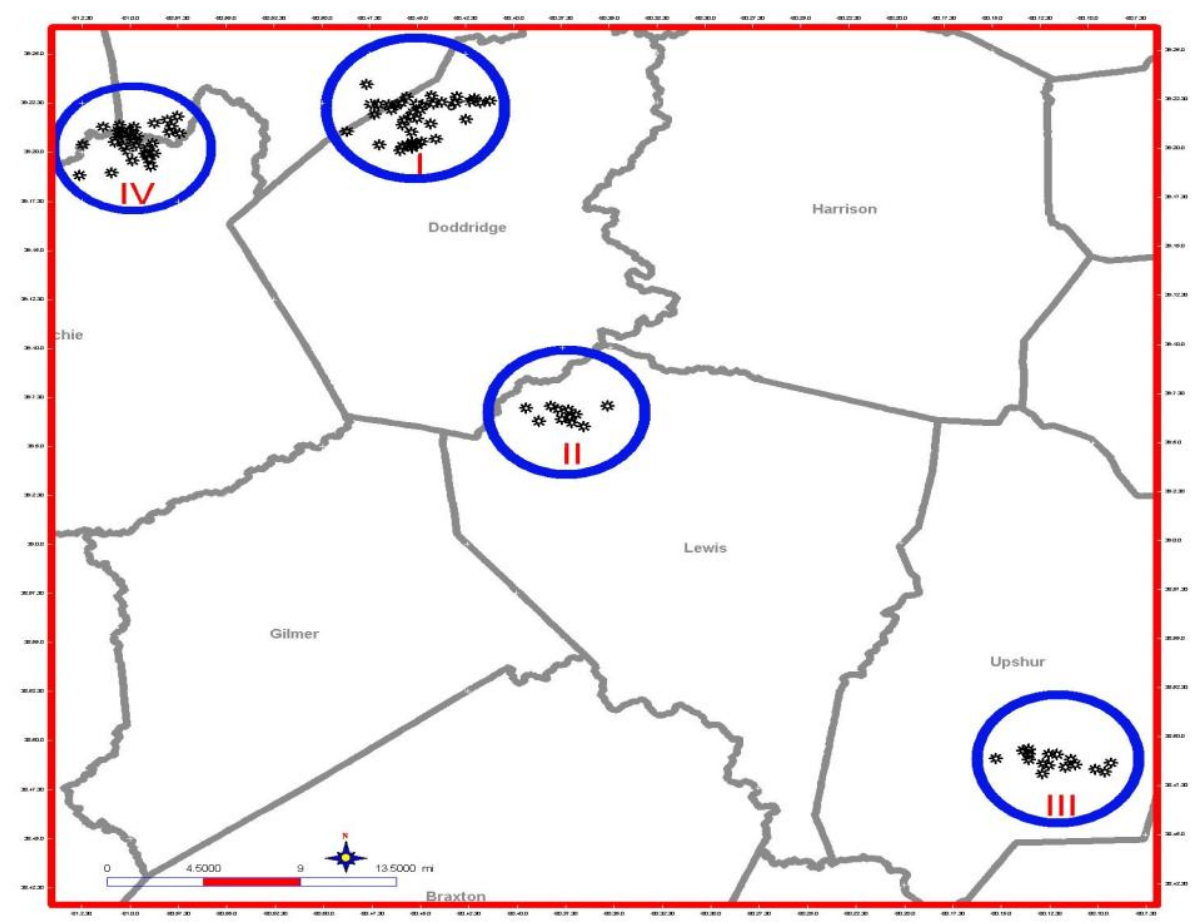

Figure 4. Selected Study Areas

\section{DATA COLLECTION}

A total of 95 wells were selected in the four areas (see Figure 4) that had sufficient data, minimum 5 years of production and $95 \%$ of the wells studied had greater than 10 years of production data available for the purpose of this study. The stimulation treatment records were obtained from Dominion and public or state (Seneca and WVGES) databases. The average injection pump rates on all the treatments were around 20-25 barrels per minute. The number of perforations per foot was constant with most all treatments at 2-3 shots per foot but the feet of perforations varied assumedly with the pay thickness. To estimate the pay thickness for all wells, Geographix system was utilized to generate an Isopach map of Benson pay thickness from density logs based on 2.55 grams/cc cut-off. Total proppant 
placed and total liquid volumes used were collected for all the wells. When Nitrogen was used in either foam fracs or Nitrogen assisted jobs, the Nitrogen gas volume was converted to a liquid volume ${ }^{10}$ (93 $\mathrm{SCF}=1$ gallon).

The production records, mainly 5-year and 10-year cumulative productions, were obtained from Dominion Aries Database. The EURs were also collected from the same Aries Database. The collected information was then compiled in Excel spreadsheet for further study. See Table 2, which is a spreadsheet of all data compiled from Area III, to help illustrate all of the variables investigated in this study.

\begin{tabular}{|c|c|c|c|c|c|c|c|c|c|c|c|c|c|c|c|c|c|c|}
\hline Well & Completed & EUR & Ft. Pay & EUR/Ft & 5 yr Cum & $5 \mathrm{yr} / \mathrm{Ft}$ & 10 yr Cum & $10 \mathrm{yr} / \mathrm{F}$ & Tot Prop & Prop/Ft & Acid Vol & Frac Typ & Perfs & Ft. Perfs & s Liq. Vol. & . N2 Vol. & Tot Vol & Frac Rate \\
\hline 1 & $11 / 01 / 81$ & 711.3 & 12 & 59.28 & 286.08 & 23.84 & 404.18 & 33.68 & 90000 & 7500 & 500 & Water & 15 & 10 & 750 & & 750 & 20 \\
\hline 2 & $10 / 01 / 81$ & 550.6 & 9 & 61.18 & 239.69 & 26.63 & 327.27 & 36.36 & 90000 & 10000 & 500 & Water & 12 & 9 & 800 & & 800 & 22 \\
\hline 3 & $07 / 01 / 81$ & 366.1 & 14 & 26.15 & 106.04 & 7.57 & 150.88 & 10.78 & 80000 & 5714 & 500 & Water & 16 & 14 & 700 & & 700 & 21 \\
\hline 4 & $10 / 01 / 81$ & 327.7 & 13 & 25.21 & 100.38 & 7.72 & 132.49 & 10.19 & 80000 & 6154 & 500 & Water & 10 & 13 & 800 & & 800 & 24 \\
\hline 5 & $09 / 01 / 75$ & 277.9 & 19 & 14.63 & 78.26 & 4.12 & 112.24 & 5.91 & 75000 & 3947 & 500 & Water & 18 & 19 & 800 & 0 & 800 & \\
\hline 6 & $12 / 01 / 87$ & 194.7 & 15 & 12.98 & 60.53 & 4.04 & 91.67 & 6.11 & 70000 & 4667 & & N2 Assist & & 15 & 400 & 750000 & 592 & 22 \\
\hline 7 & $12 / 01 / 74$ & 175.0 & 12 & 14.58 & 32.70 & 2.73 & 52.80 & 4.40 & 65000 & 5417 & 500 & Water & & 12 & 750 & 0 & 750 & \\
\hline 8 & $08 / 01 / 83$ & 163.1 & 3 & 54.38 & 43.65 & 5.46 & 63.53 & 7.94 & 60000 & 20000 & 500 & Water & 10 & 8 & 550 & & 550 & 20 \\
\hline 9 & $04 / 01 / 88$ & 137.9 & 4 & 34.49 & 41.53 & 8.31 & 58.87 & 11.77 & 55000 & 13750 & & N2 Assist & & 5 & 574 & 422000 & 682 & 23 \\
\hline 10 & $12 / 01 / 82$ & 117.7 & 8 & 14.71 & 41.30 & 5.16 & 60.01 & 7.50 & 40000 & 5000 & & Water & & 8 & 147 & 405000 & 251 & 22 \\
\hline 11 & $11 / 01 / 88$ & 112.8 & 3 & 37.60 & 32.78 & 10.93 & 46.72 & 15.57 & 50000 & 16667 & & Foam & 10 & 3 & 325 & 457200 & 442 & \\
\hline 12 & $01 / 01 / 03$ & 104.8 & 3 & 34.93 & 39.49 & 13.16 & 56.25 & 18.75 & 45000 & 15000 & & Water & & 3 & 436 & & 436 & 20 \\
\hline 13 & $05 / 01 / 03$ & 104.1 & 3 & 34.71 & 49.50 & 16.50 & 64.25 & 21.42 & 50000 & 16667 & & Foam & & 3 & 214 & 350000 & 304 & 24 \\
\hline 14 & $10 / 01 / 83$ & 90.1 & 5 & 18.03 & 24.79 & 4.96 & 38.63 & 7.73 & 50000 & 10000 & 500 & Water & 10 & 5 & 650 & & 650 & \\
\hline 15 & $09 / 01 / 75$ & 87.5 & 5 & 17.49 & 18.70 & 3.74 & 30.73 & 6.15 & 55000 & 11000 & 500 & Water & 18 & 6 & 700 & 0 & 700 & \\
\hline 16 & $11 / 01 / 88$ & 78.2 & 9 & 8.69 & 15.28 & 1.70 & 24.57 & 2.73 & 56000 & 6222 & & Foam & 15 & 9 & 266 & 422000 & 374 & 21 \\
\hline
\end{tabular}

Table 2. Area III Compiled Data

Area I contains 40 wells with pay thickness ranging from 3-8 feet, EUR varying from 44-275 MMcf. The total liquid volume used during stimulation ranged from 377 Bbls up to $868 \mathrm{Bbls}$ and total proppant placed ranged from 30,000 Lbs to 80,000 Lbs. The type of frac for this area was $65 \%$ were water fracs and $35 \%$ were water with Nitrogen assist, and frac rate data was available for 31 of the 40 wells with and average of $23 \mathrm{bpm}$ rate. Area II contains 11 wells with pay thickness ranging from 2-19 feet, EUR varying from 90-891 
MMcf. The total liquid volume ranged from $274 \mathrm{Bbls}$ up to $800 \mathrm{Bbls}$ and total proppant placed ranged from $35,000 \mathrm{Lbs}$ to $105,000 \mathrm{Lbs}$. The frac type for this area was evenly split with 3 water, 4 nitrogen assist, and 4 foam fracs. Frac rate data was available for 8 out of the 11 and the average was $22 \mathrm{bpm}$. Area III contains 16 wells with pay thickness ranging from 3-19 feet, EUR varying from 78-711 MMcf. The total liquid volume ranged from 251 Bbls up to 800 Bbls and total proppant placed ranged from 40,000 Lbs to 90,000 Lbs. The type of frac used in this area was 8 water, 3 foam, and 2 nitrogen assist fracs. Frac rate data was available for 11 of the 16 wells and the average was 22 bpm rate. Finally, Area IV contains 28 wells with pay thickness ranging from 3-10 feet, EUR varying from 22-325 MMcf. The total liquid volume was available for 23 of the 28 wells ranging from 440 bbls to 980 bbls. Total proppant placed ranged from 23,000 Lbs to 80,000 Lbs. The frac types for this area were 25 foam and 3 water fracs. Frac rate data was available for 22 of the 28 wells and the average was $21 \mathrm{bpm}$ rate.

The stimulation treatment fluid type for most of the wells was linear gelled water at $44 \%$, then foam at $34 \%$ and the remaining $22 \%$ were water with nitrogen assist. The average pump rate and shots per foot did not seem to have enough variance to be a factor in the study. The average pump rate from all the data available was found to be $22.1 \mathrm{bpm}$ pump rate and the range was from $18-26 \mathrm{bpm}$. The size of the perforations was only available on a few of the wells and the shots per foot ranged from 1-3 shots per foot. The relationship between cumulative production (or EUR) and all variables of the stimulation procedure were investigated. 


\section{Data Analysis}

With some of the data collected and compiled into Microsoft Excel the 5 year cumulative gas production per Foot of Pay vs all individual stimulation parameters was plotted to try and find correlations. Then 5 year cumulative gas production was plotted vs Feet of pay to find if correlation exists. Knowing that feet of pay had no correlation to 5 year cumulative production, then 5 year cumulative production vs all the stimulation parameters independently were plotted and found some correlations with total liquid injected and also a better correlation with total proppant placed.

With all data compiled and individual study areas divided, again 5 year and also 10 year cumulative production was plotted vs all the stimulation parameters for just Area I, and total liquid injected and total proppant had the best correlation to production. EUR was then plotted vs total liquid injected and total proppant with very similar results found as cumulative production. The decision to use EUR instead of cumulative production for the rest of the study was made due to the way Aries calculates the rate of return for the investment of a well. Now the focus of the study was on EUR vs total proppant and total injection fluid because they both had the best correlation and also on EUR vs feet of pay because no correlation was found and this was surprising. It was expected that feet of pay would have a direct correlation to production and EUR.

After results of the analysis of Area I, the primary focus of the study was on EUR vs total proppant placed during stimulation for the other 3 study areas and also the Total Study Area. The results can be seen in the Results portion of the paper. 


\section{Production History Analysis}

Production history analysis was performed using Aries and Fekete RTA software. All data needed for analysis was supplied by the operator and compiled into a database. Aries was the primary tool used to get EURs and decline curve parameters. Fekete was used to verify the EURs and also investigate some of the reservoir properties, such as permeability, skin, and also drainage area. The results were then used in the economic portion of the research.

\section{Economic Analysis}

To perform an economic analysis, the well costs were necessary for all scenarios. A current average well depth of 5,260 feet was used for cost estimates. The estimate was supplied by the operator and is a total cost excluding stimulation, ready to turn in line. The stimulation cost for Hydraulic water frac, mimicking the jobs done in the study were supplied by a service provider in the Appalachian Basin. The job costs were estimated based on total proppant placed from $30,000 \mathrm{Lbs}$ to $120,000 \mathrm{Lbs}$ and the injection fluid volume need to adequately place this volume of sand. Table 3 summarizes the total well cost with different amount of proppant placed. Table 4 is a breakdown of all the cost associated with drilling a well ready to turn in line, excluding stimulation cost. 


\begin{tabular}{|c|c|}
\hline Proppant Placed (Lbs) & Total Job Cost (\$) \\
\hline 30,000 & 325,907 \\
\hline 40,000 & 328,977 \\
\hline 50,000 & 332,310 \\
\hline 60,000 & 335,211 \\
\hline 70,000 & 338,866 \\
\hline 80,000 & 343,698 \\
\hline 90,000 & 344,626 \\
\hline 100,000 & 349,128 \\
\hline 110,000 & 349,663 \\
\hline 120,000 & 352,634 \\
\hline
\end{tabular}

Table 3: Total Well Cost including Stimulation Treatment

\begin{tabular}{|l|r|}
\hline \multicolumn{2}{|c|}{ Well Cost } \\
\hline Land \& Legal & $\$ 33,750.00$ \\
\hline Location \& Road & $\$ 55,614.00$ \\
\hline Completion Contractor & $\$ 128,604.00$ \\
\hline Completion Materials & $\$ 46,948.00$ \\
\hline Pipeline and Meter & $\$ 10,047.00$ \\
\hline Wellhead \& Surface Equipment & $\$ 25,300.00$ \\
\hline Total & $\$ 300,263.00$ \\
\hline
\end{tabular}

Table 4. Well Cost Breakdown 
Table 5 shows the stimulation costs for the various size jobs that were used in the analysis of this study. These cost were estimates based on $25 \mathrm{bpm}$ pump rates, the total amount of injection fluid, chemical and equipment needed to place the proppant volumes.

\begin{tabular}{|c|c|}
\hline Job Size (Lbs) & Stimulation Costs \\
\hline 30,000 & $\$ 12,067.68$ \\
\hline 40,000 & $\$ 13,512.48$ \\
\hline 50,000 & $\$ 15,080.96$ \\
\hline 60,000 & $\$ 16,446.24$ \\
\hline 70,000 & $\$ 18,165.76$ \\
\hline 80,000 & $\$ 20,439.84$ \\
\hline 90,000 & $\$ 20,876.48$ \\
\hline 100,000 & $\$ 22,994.88$ \\
\hline 110,000 & $\$ 23,247.20$ \\
\hline 120,000 & $\$ 24,645.60$ \\
\hline
\end{tabular}

Table 5. Stimulation Cost Estimates

With all data analyzed, production decline parameters available, and costs estimated, Aries is used to perform the economic analysis based on the stimulation variable that had the greatest impact on production or EUR. 


\section{Chapter 4}

\section{RESULTS AND DISCUSION}

\section{Production vs Liquid Volume}

The first parameter that was studied independently with EUR or production was total liquid volume injected. It is reasonable to assume that the total liquid volume has some impact on the production and EUR. A plot of cumulative production against total liquid volume injected for Area I is illustrated in Figure 5. Although, there appears a relationship may exist between the two variables, a significant correlation does not exist. Indeed, no significant correlation can be obtained in any of the four areas.

\section{Production vs Total Proppant}

The main variable that was studied is total proppant placed during stimulation. Reasonable correlations between EUR or 5-year and 10-year cumulative productions and total proppant placed were found in all four areas. Plots of EUR against total proppant placed for all four areas as well as the total study area (all the wells in the four areas) are illustrated in Figures 6 through 10. Finally, the relationship between total liquid and total proppant was investigated. It is believed to place more proppant, more liquid volume may be necessary. A plot of total proppant placed against total liquid volume injected for Area I is illustrated in Figure 11. It appears from Figure 11 that a relationship between total liquid and total proppant is present but again it is not significant. 
Based on the results it appears that total amount of proppant placed has the greatest impact on cumulative production and EUR. If all other variables were kept constant and only the total amount of proppant was changed, the EUR of a well could be predicted based on developed correlations for different areas.

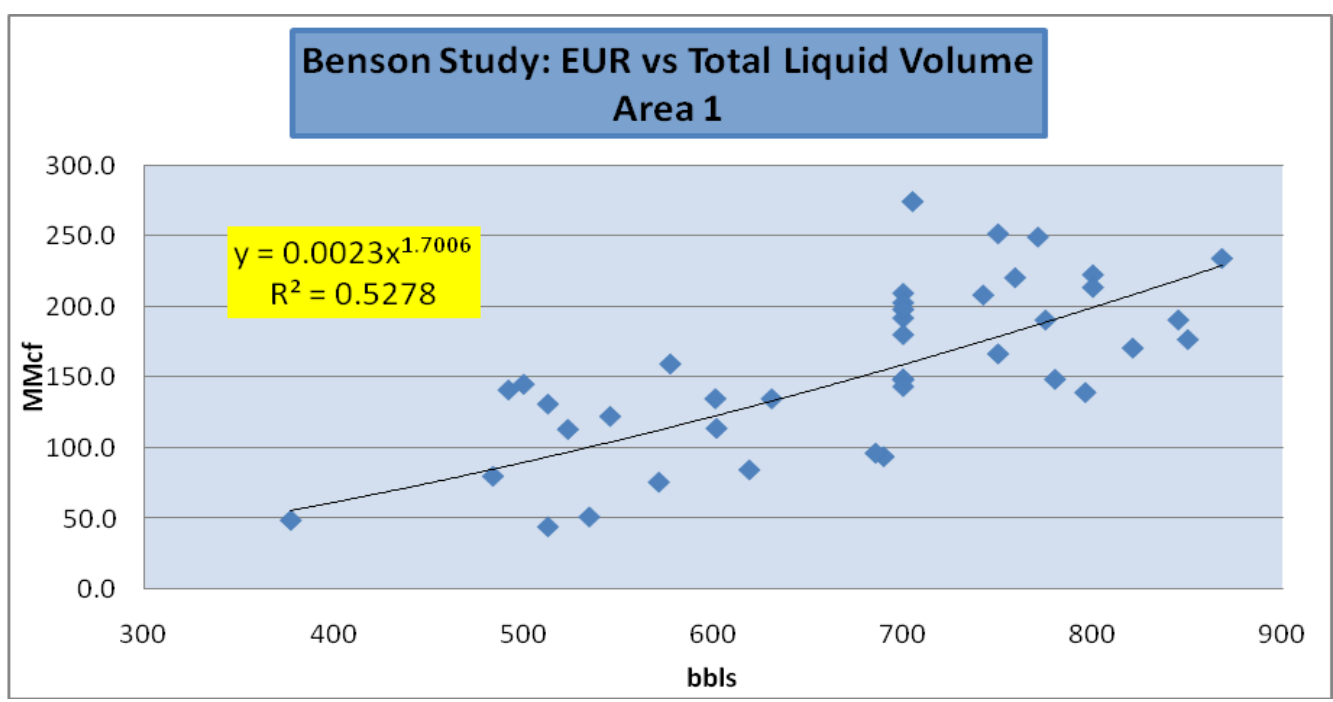

Figure 5. The Relation between EUR and Total Volume of Fluid Injected for Area I

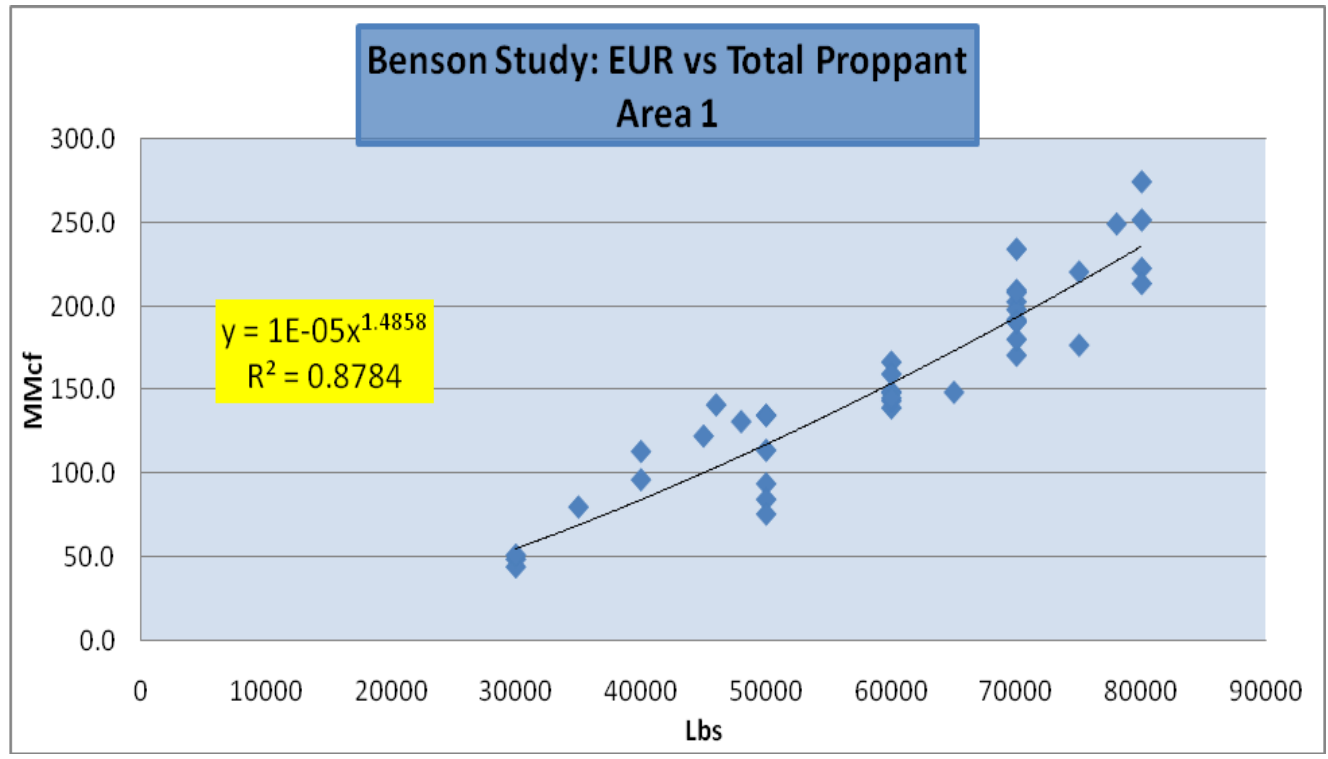

Figure 6. The Relation between EUR and Total Proppant Placed for Area I 


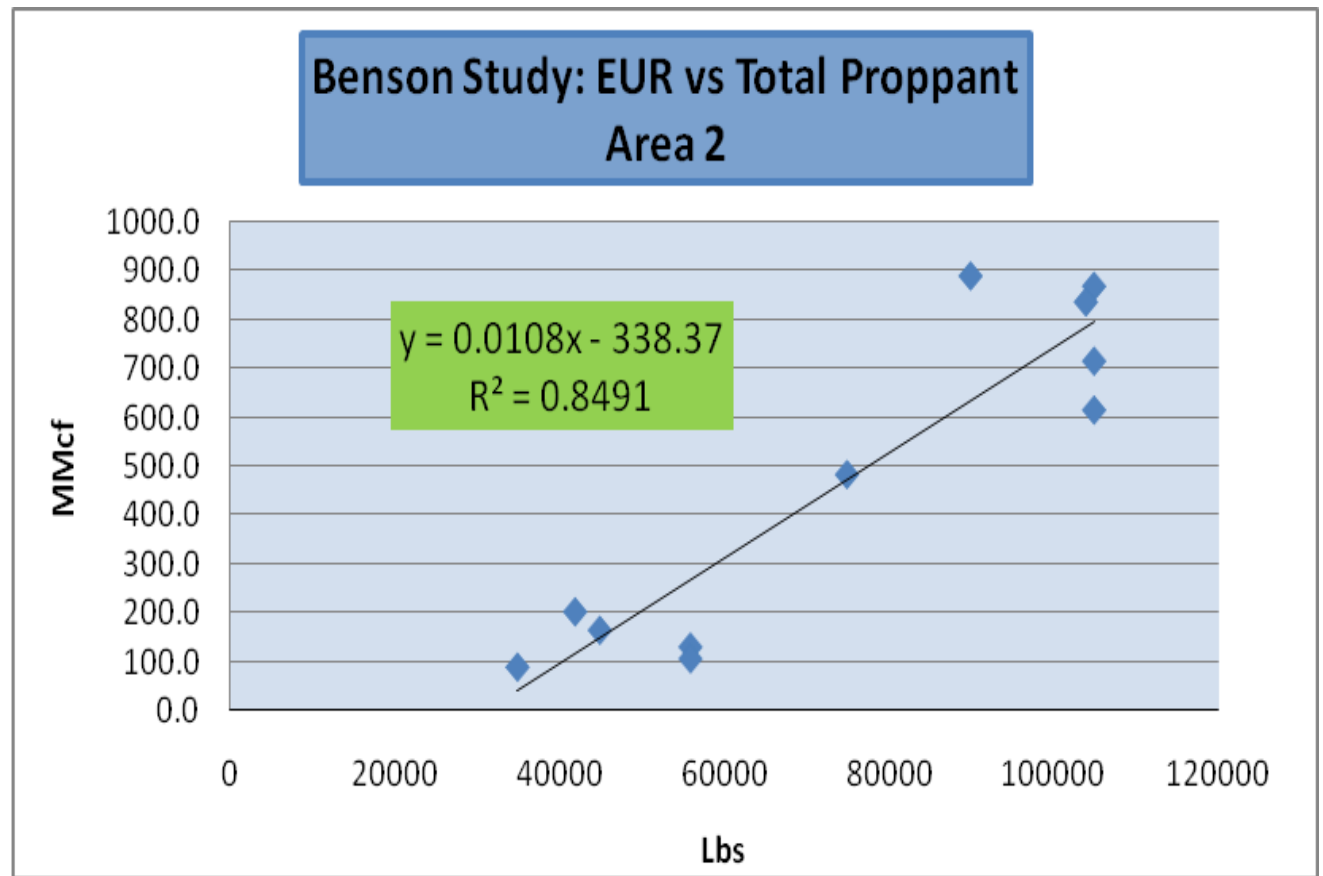

Figure 7. The Relation between EUR and Total Proppant Placed for Area II

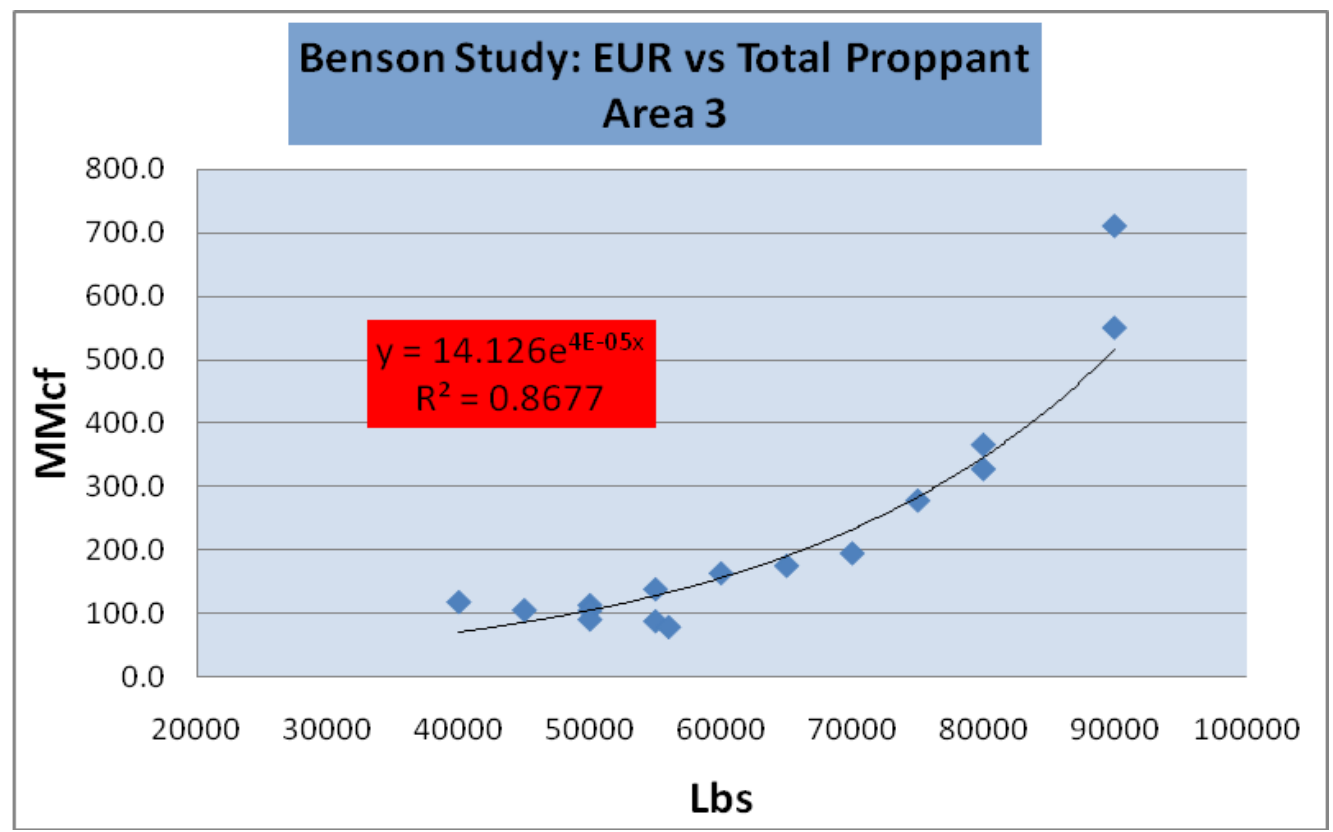

Figure 8. The Relation between EUR and Total Proppant Placed for Area III 


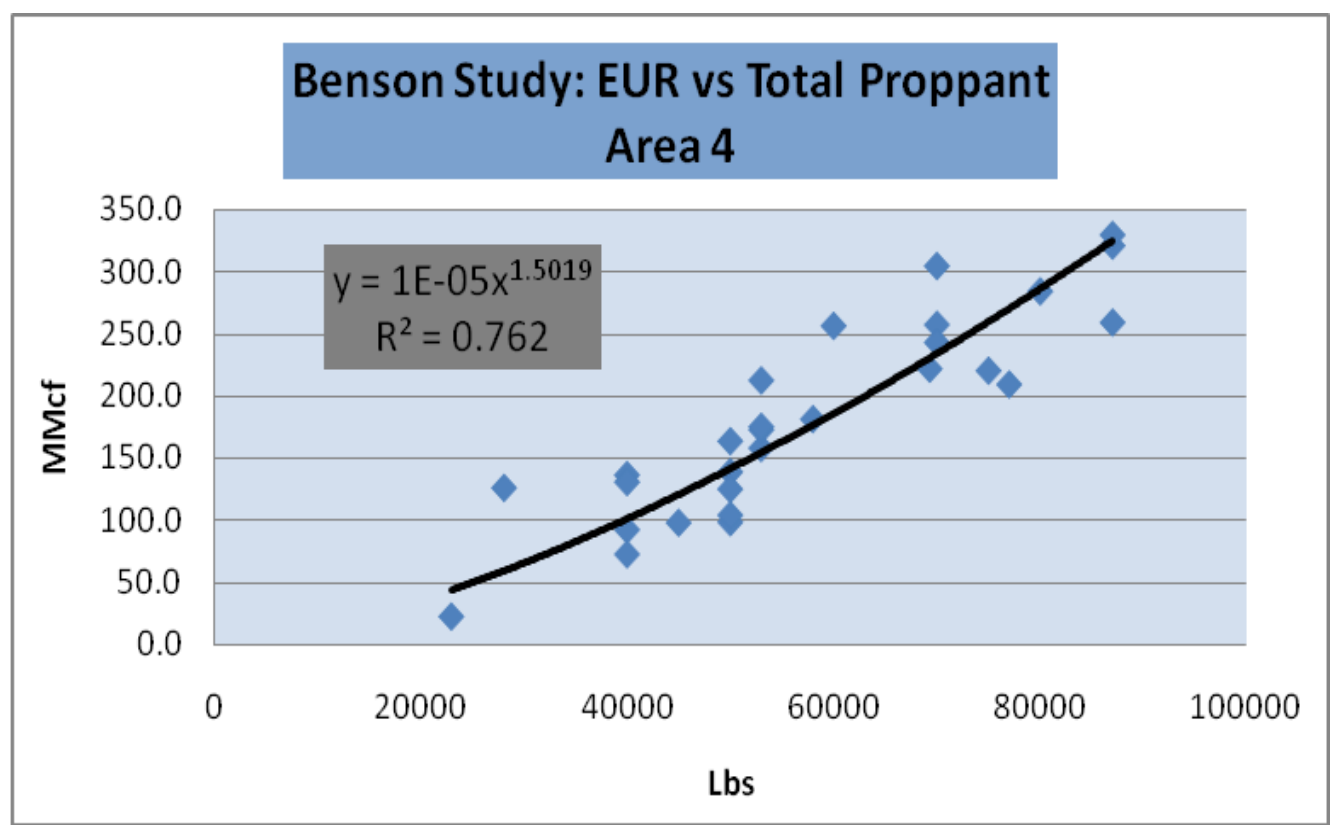

Figure 9. The Relation between EUR and Total Proppant Placed for Area IV

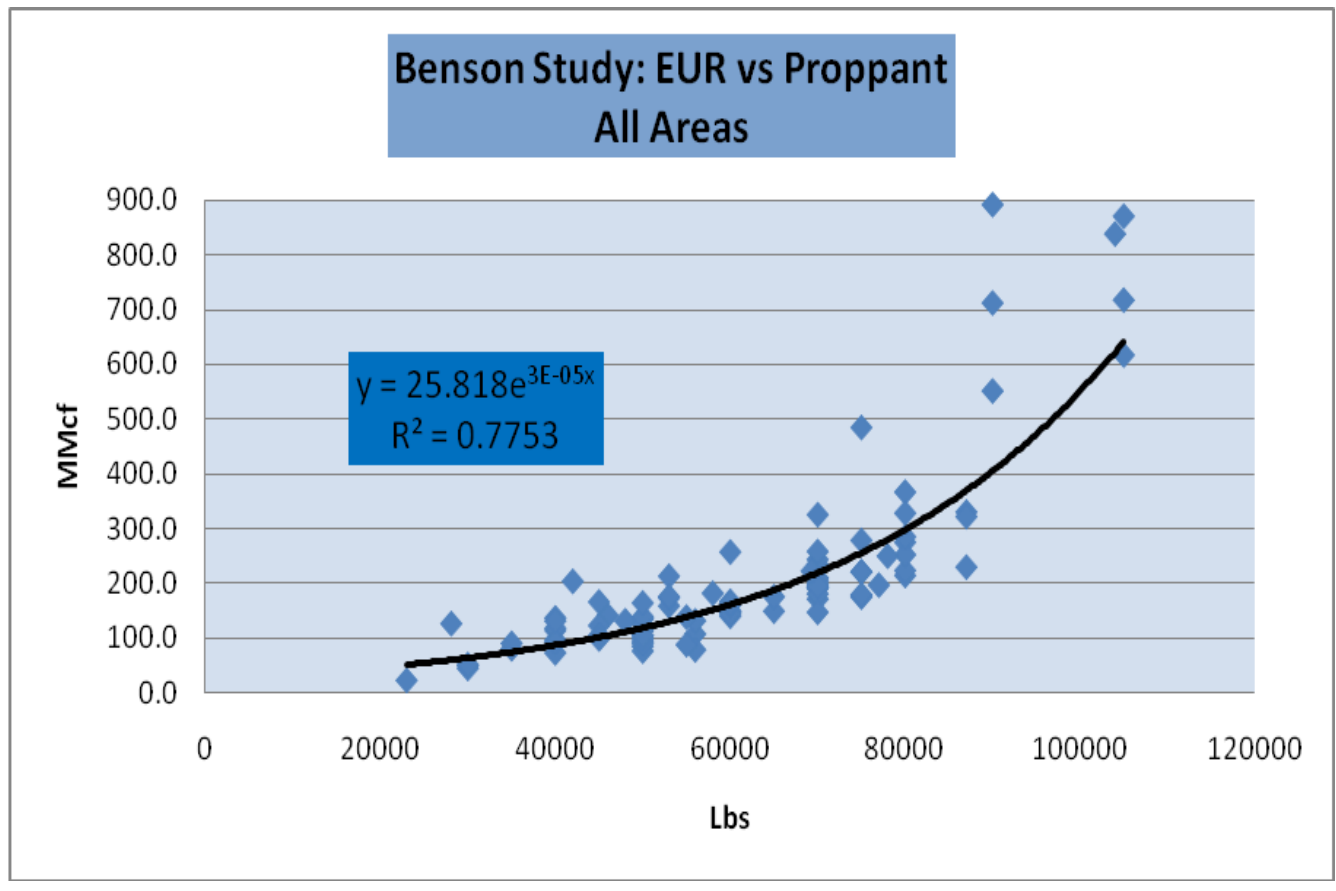

Figure 10. The Relation between EUR and Total Proppant Placed for the Total Study Area 


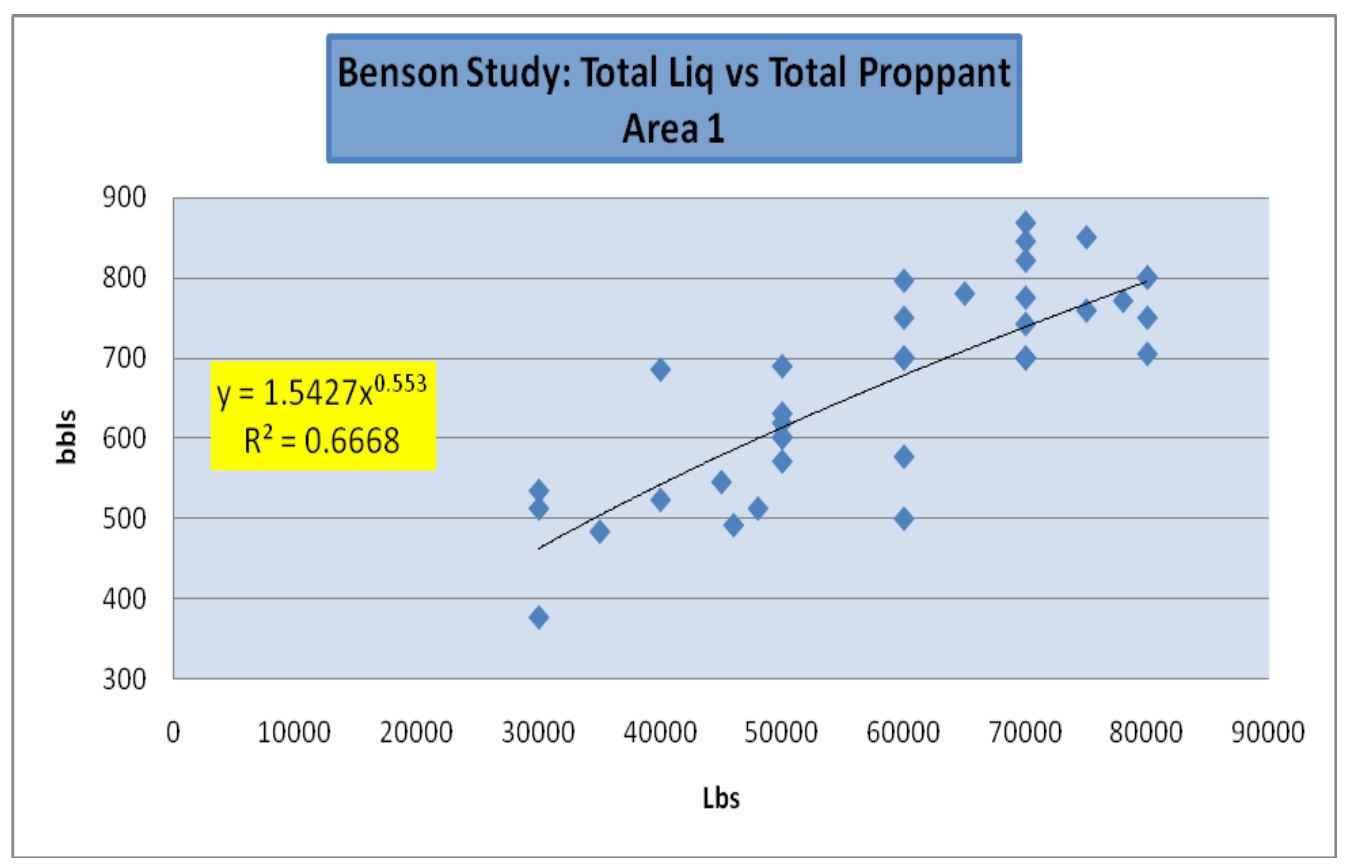

Figure 11. Total Volume of Fluid Injected vs Total Proppant Placed Area I

\section{Production History Analysis}

To investigate the impact of total proppant placed on production in more detail, three wells with the same amounts of proppant placed in Area I were selected for production history analysis using Fekete Fast RTA ${ }^{\mathrm{TM}}$ Version 3.207 software $^{11}$. Well 1 had 35,000 Lbs of proppant placed, Well 2 had 50,000 Lbs of proppant placed and Well 3 had 75,000 Lbs of proppant placed. The production records were imported into Fekete from Dominion's ARIES database. Reservoir properties such as initial pressure, thickness, depth and porosity were found in well files at Dominion along with well completion information. After all information was loaded into Fekete software, Fetkovich type curve analysis was performed on all wells and the best fit trend lines were found for the rate vs. time and rate vs.

cumulative production. Figures 12, 13, and 14 illustrate the results of the analysis for Area I. 
The same analysis of 3 wells in Area II was also performed using Fekete and results are in Table 7.

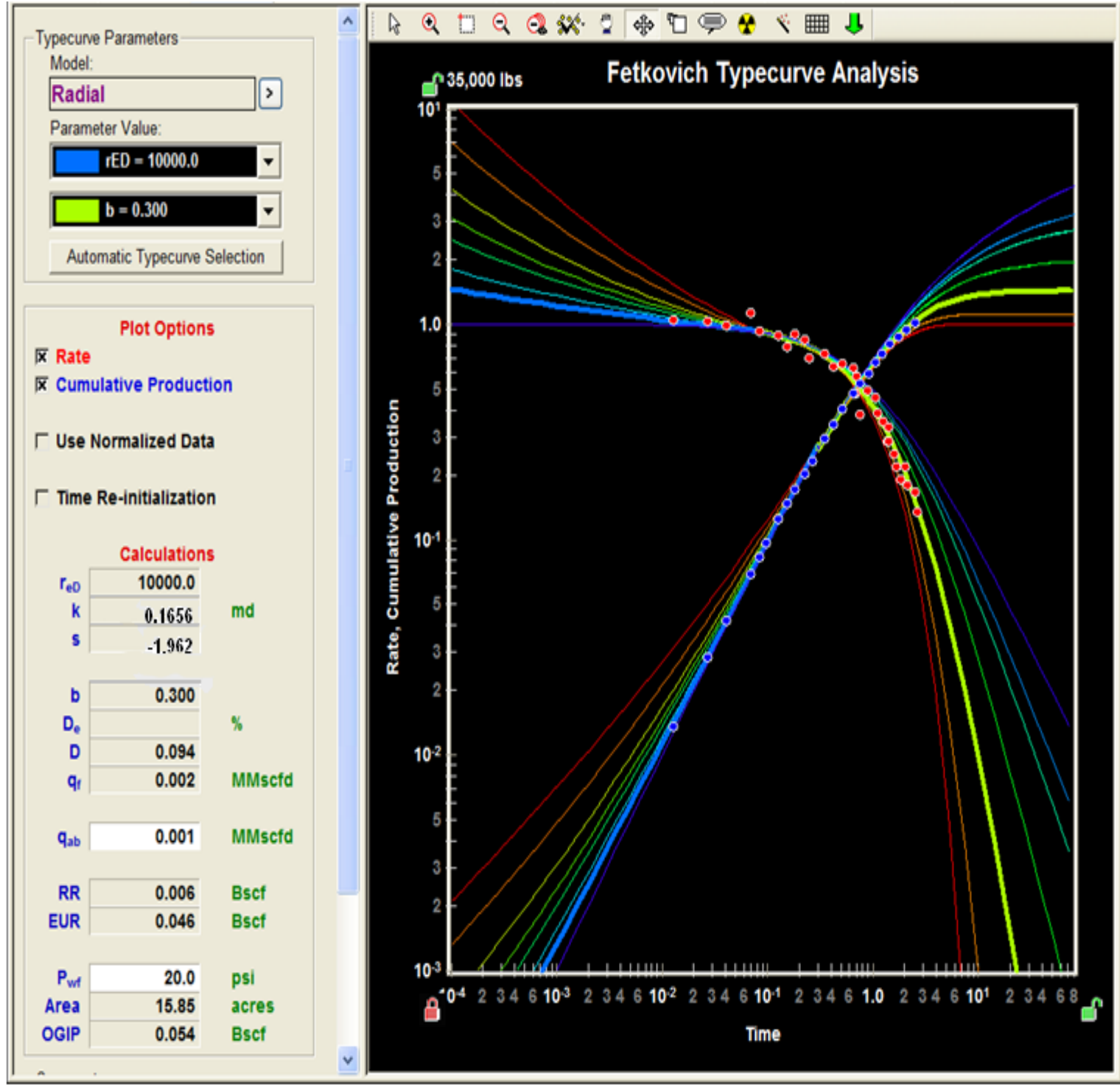

Figure 12: Well 1, Area I 35,000 Lbs of Proppant Placed 


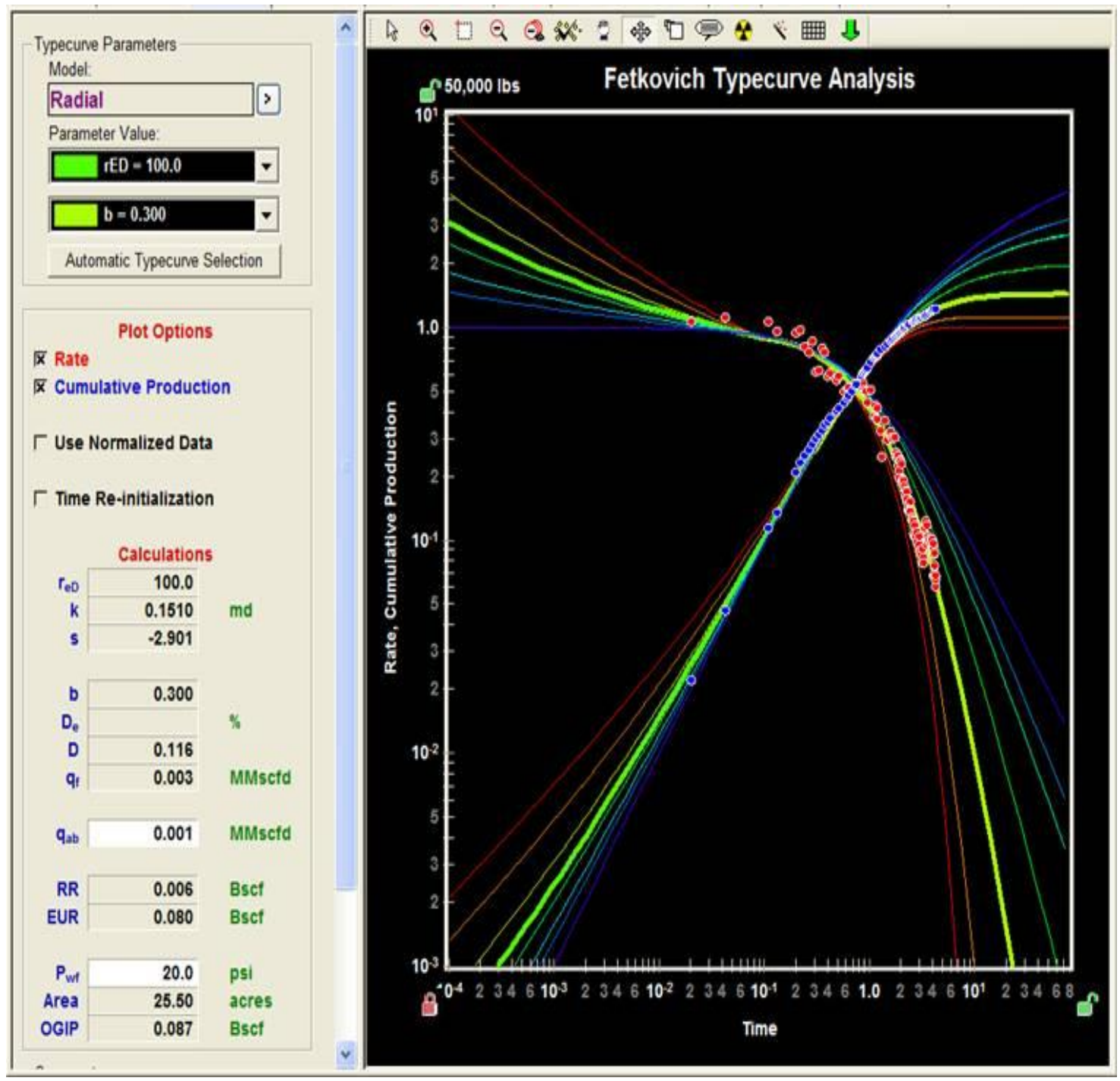

Figure 13: Well 2, Area I 50,000 Lbs of Proppant Placed 


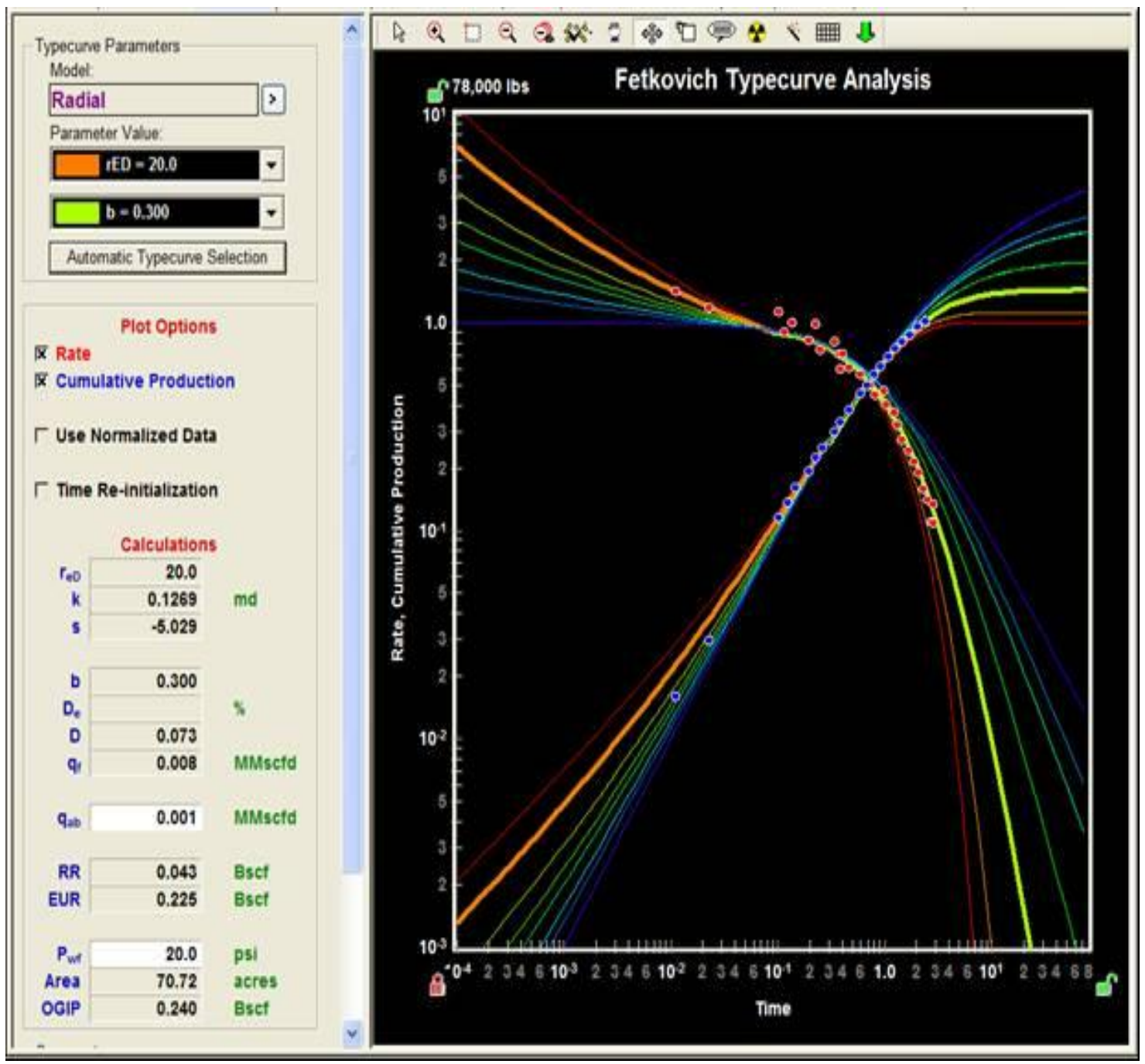

Figure 14: Well 3, Area I 78,000 Lbs of Proppant Placed

It is interesting to note the type curve analysis indicated that the permeability for Area I, Wells 1, 2 and 3 are 0.13-0.16 milidarcy and for Area II, wells 1, 2, and 3 are 0.08-0.09 milidarcy. These very low permeability values might explain why cumulative production (and EUR) would have much less dependency on pay thickness than on proppant placed. Core samples were found in the records from the operator for 2 of the wells that were chosen to 
perform production analysis using Fekete to help support the finding. From the core data the permeabilities found using Fekete matched very closely. Also the EURs using Fekete software was a match to the EURs from Aries decline curve analysis.

Furthermore, the analysis of the production history using Fekete software, indicates that in Area I, the drainage area for Well 2 is 61 percent greater than Well 1 and Well 3 is 350 percent greater. Area II Well 2 drainage area is 170 percent greater than Well 1 and Well 3 is 440 percent greater. In Area I when proppant was increased by $42 \%$, the drainage area was increased by $61 \%$, when the proppant was increased by $122 \%$, the drainage area was increased by $350 \%$. In Area II when proppant was increased by $50 \%$, the drainage area was increased by $170 \%$, when the proppant was increased by $110 \%$, the drainage area was increased by $440 \%$. This indicates that increasing the total proppant placed during stimulation not only increases production and EUR but also decreases the number of wells needed to effectively drain the reservoir. See Table 6 and 7 for results of the production history analysis using Fekete RTA software.

\begin{tabular}{|c|c|c|c|c|c|}
\hline Prop (lbs) & $\begin{array}{c}\text { EUR } \\
\text { (MMcf) }\end{array}$ & $\begin{array}{c}\text { Well Cost } \\
\mathbf{( \$ )}\end{array}$ & $\begin{array}{c}\text { Drainage } \\
\text { Area }\end{array}$ & $\begin{array}{c}\text { Perm } \\
(\mathbf{m d})\end{array}$ & Skin \\
\hline 35,000 & 49 & 327,500 & 16 acres & 0.16 & -1.962 \\
\hline 50,000 & 94 & 332,000 & 26 acres & 0.15 & -2.901 \\
\hline 78,000 & 249 & 342,000 & 71 acres & 0.13 & -5.029 \\
\hline
\end{tabular}

Table 6: Area I, All wells have 4 feet of pay and similar reservoir pressure 


\begin{tabular}{|c|c|c|c|c|c|}
\hline $\begin{array}{c}\text { Prop } \\
\text { (Ibs) }\end{array}$ & $\begin{array}{c}\text { EUR } \\
\text { (MMcf) }\end{array}$ & $\begin{array}{c}\text { Well Cost } \\
(\mathbf{\$})\end{array}$ & $\begin{array}{c}\text { Drainage } \\
\text { Area }\end{array}$ & $\begin{array}{c}\text { Perm } \\
(\mathbf{m d})\end{array}$ & Skin \\
\hline 50,000 & 180 & 332,310 & 27 acres & 0.08 & -2.805 \\
\hline 75,000 & 484 & 341,300 & 45 acres & 0.09 & -4.983 \\
\hline 105,000 & 870 & 349,350 & 118 acres & 0.08 & -5.736 \\
\hline
\end{tabular}

Table 7: All wells have 4 feet of pay and similar reservoir pressure

\section{Economics}

To come up with a typical well, both Area I and the Total Study Area were considered. Area I was selected because it had the lowest average production and would represent the most conservative scenario for economic analysis. The total study area was selected to represent the average for a Benson well independent of location. In both Area I and the Total Study Area, ARIES software was used to estimate the production decline curve parameters with Rate-Time Semi-Log Plots, namely initial annual decline percentage $\left(D_{e}\right)$, hyperbolic slope exponent $(b)$ and minimum hyperbolic decline or terminal decline $\left(D_{\min }\right)$, for the type curves. ${ }^{12}$ A sample of wells with varying size stimulations were initially chosen for decline curve analysis, assuming the well with larger stimulation jobs would have a different curve shape than a well with a smaller stimulation. This was not the case, all wells had very similar decline curve parameters, except the initial gas production rate. The wells with larger stimulation jobs done had higher initial production rates. The decline curve parameters were achieved by combining all 40 wells in Area I and all 95 wells for the Total Study Area. The decline parameters for Area I were found to be as follows, $D_{e}$ $=20.8 \%, b=0.65$ and $D_{\min }=4.0 \%$. For the Total Study Area, the parameters were found to 
be as follows, $D_{e}=19.4 \%, b=0.94$ and $D_{\min }=4.0 \%$. See Figure 15 for an example Trend Line Plot from Aries using the actual gas production from Area I.

All EUR values were calculated based on the correlation and trend line equations from the data analysis in Area I and the Total Study Area. See Figures 16 and 17 for Area I and Total Study Area EUR values that correspond to the total amount of proppant placed. With EUR values set for both groups, and decline curve parameters available, a property in ARIES was built for all cases. All associated cost including operating and maintenance costs, royalties, and taxes were included. Using the NYMEX Forward Strip gas prices from July 2009 starting at $\$ 4.90 / \mathrm{Mcf}$ and peaking at $\$ 10.15 / \mathrm{Mcf}$, the economic analysis was performed and the after tax rate of return (ATAX ROR) and finding and development, $(\mathrm{F} \& \mathrm{D})$ costs are calculated. The economic calculations are based on a $100 \%$ working interest and a $87.5 \%$ Net Revenue Interest. Figures 18 through 21 illustrate the results. Tables 8 and 9 summarize the economic results for Area I and also the Total Study Area.

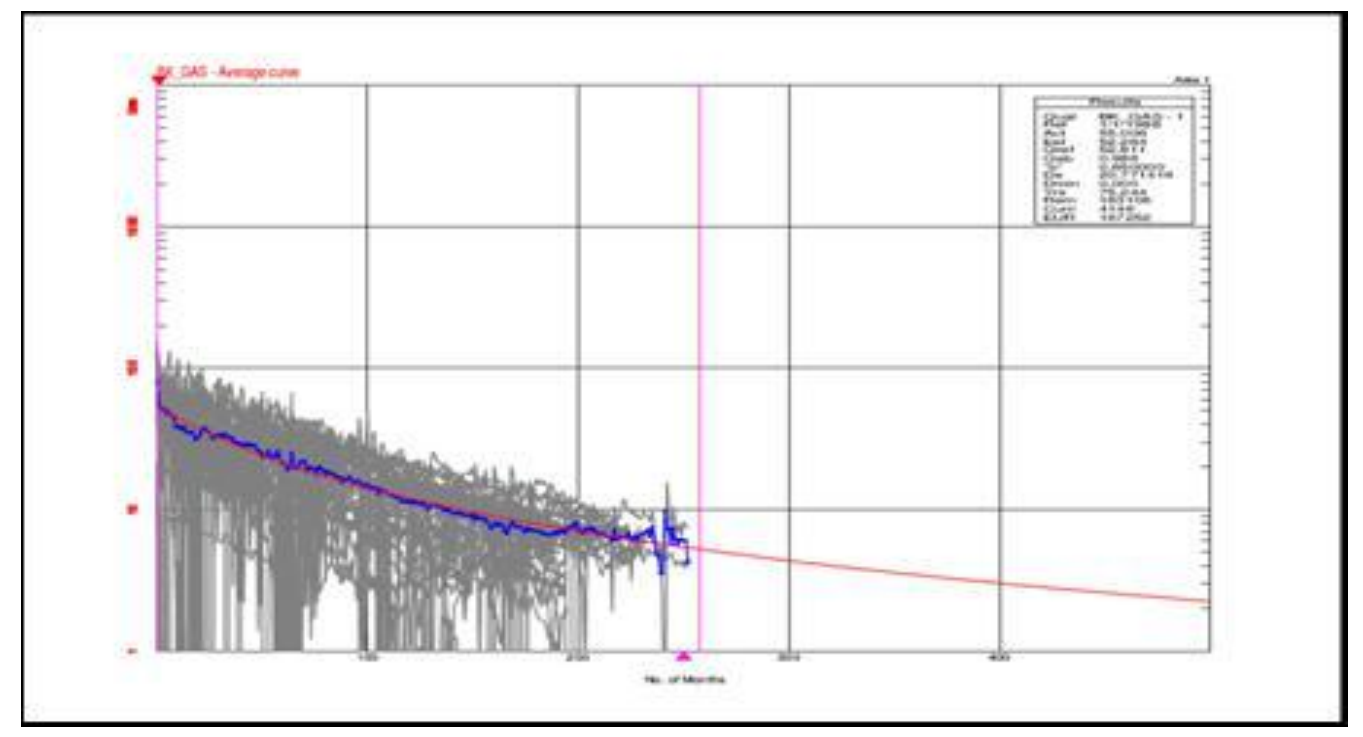

Figure 15: Production Decline Curve Analysis in ARIES for Area I 


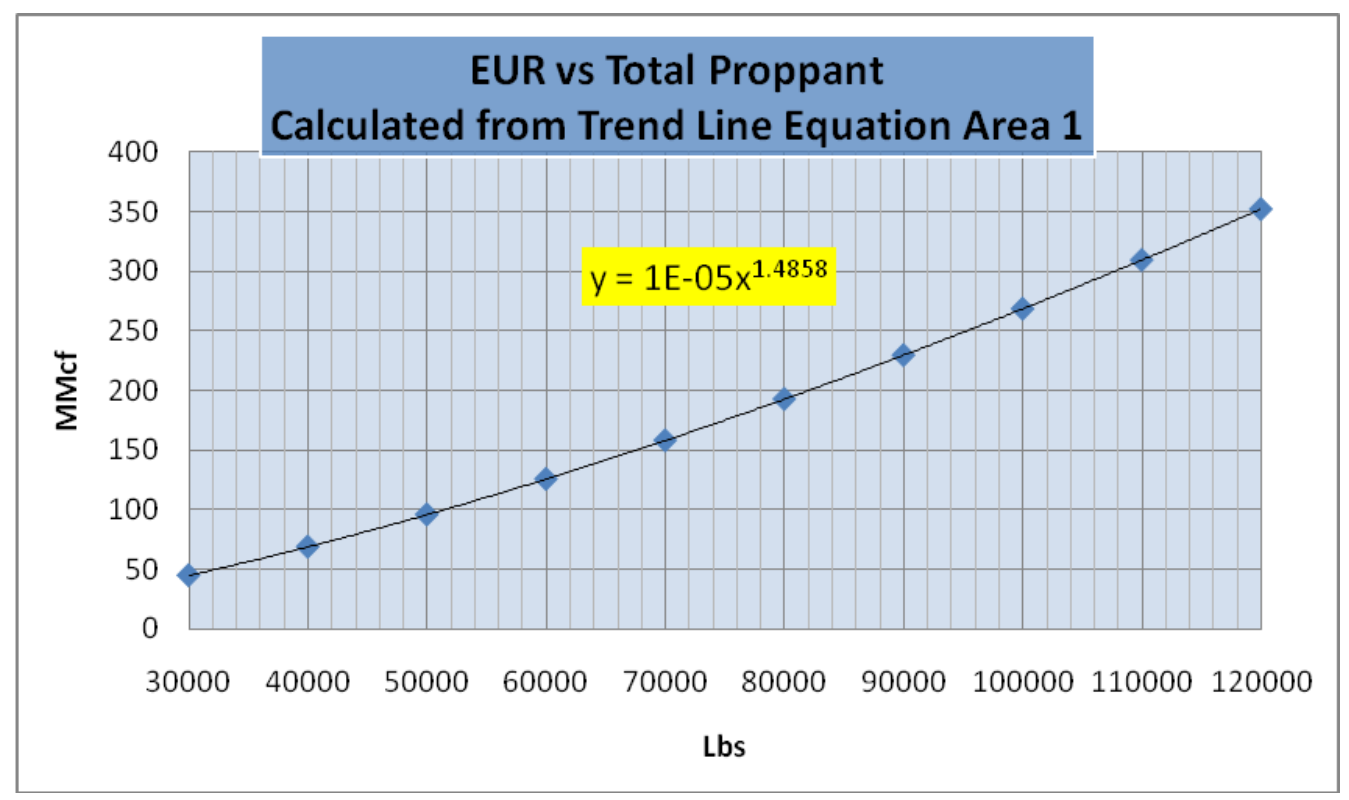

Figure 16: EUR Values Based on Total Proppant Place in Area I

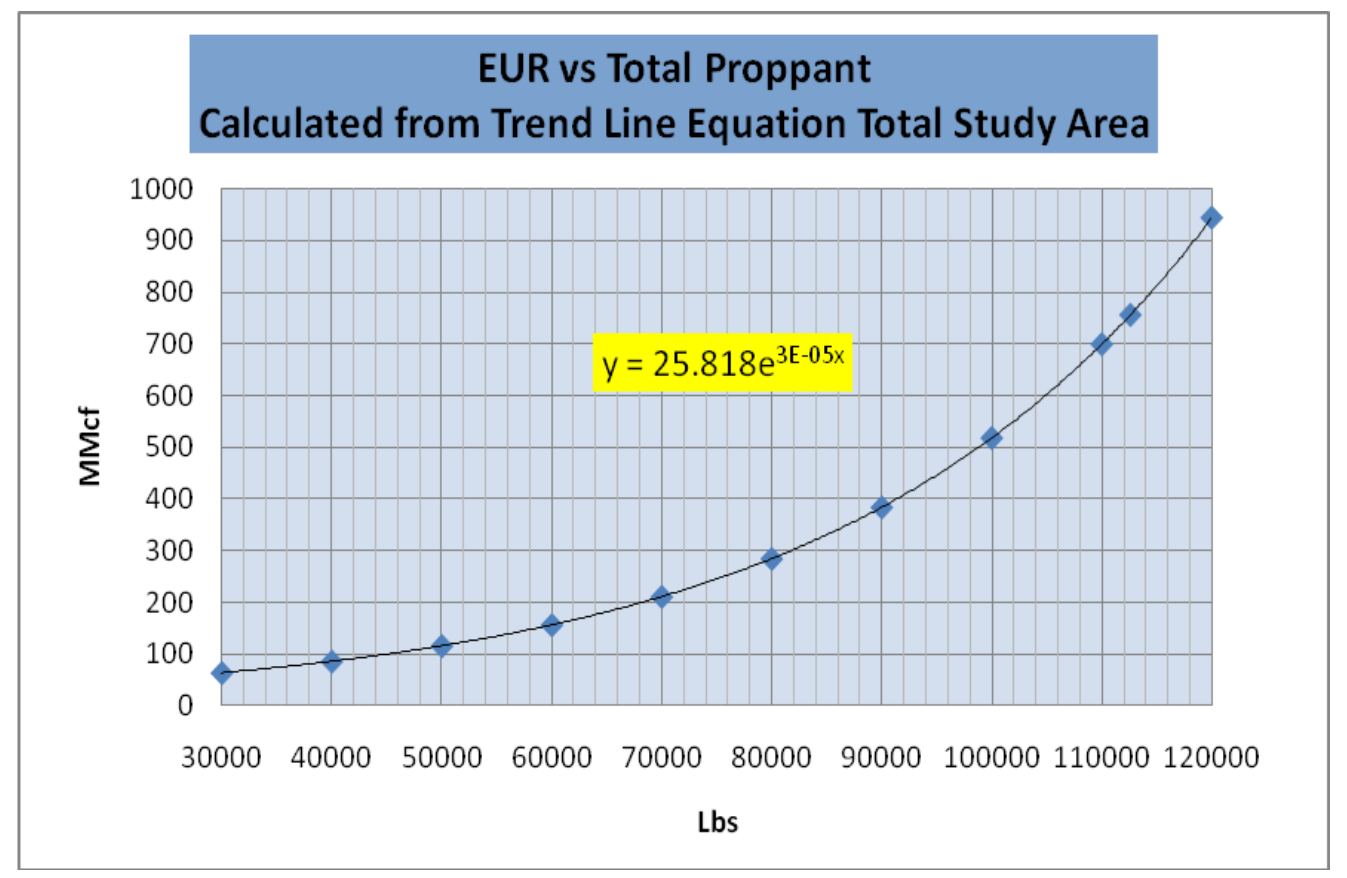

Figure 17: EUR Value Based on Total Proppant Placed Total Study Area 


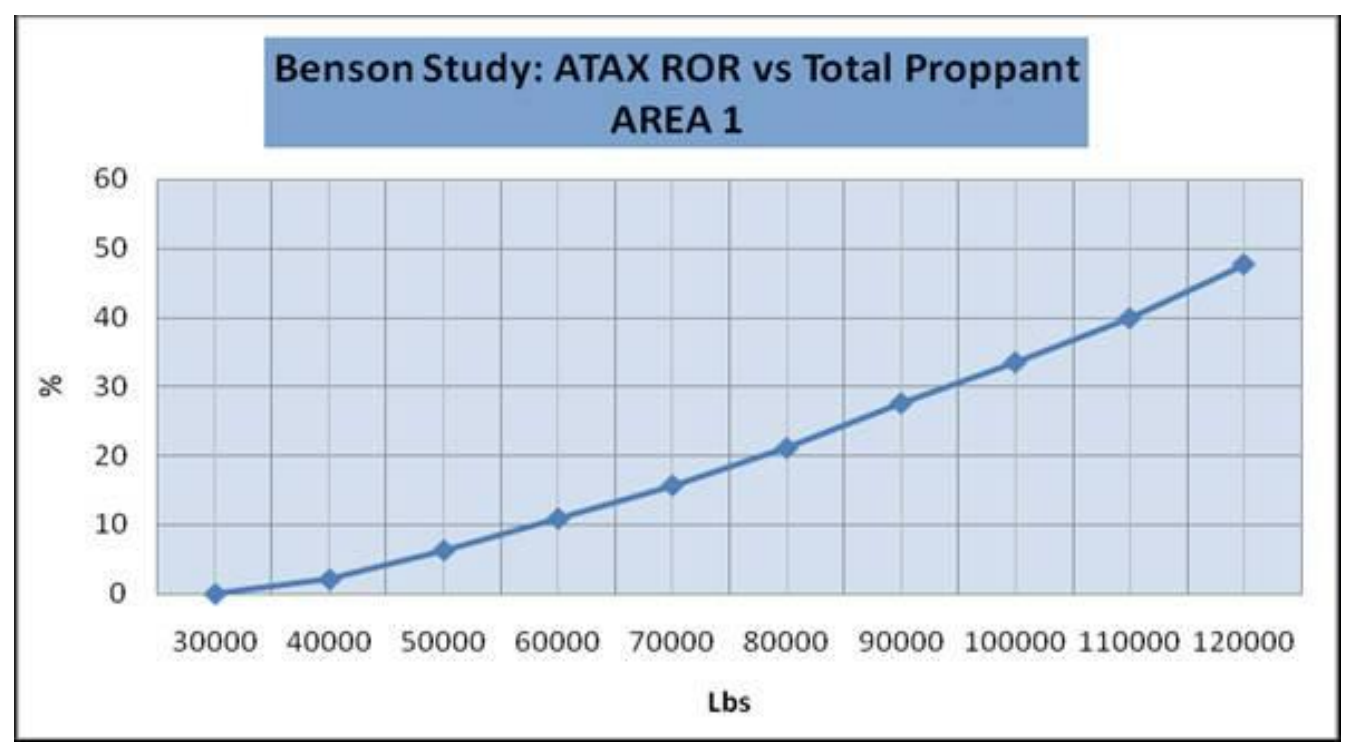

Figure 18: ATAX ROR for Area I

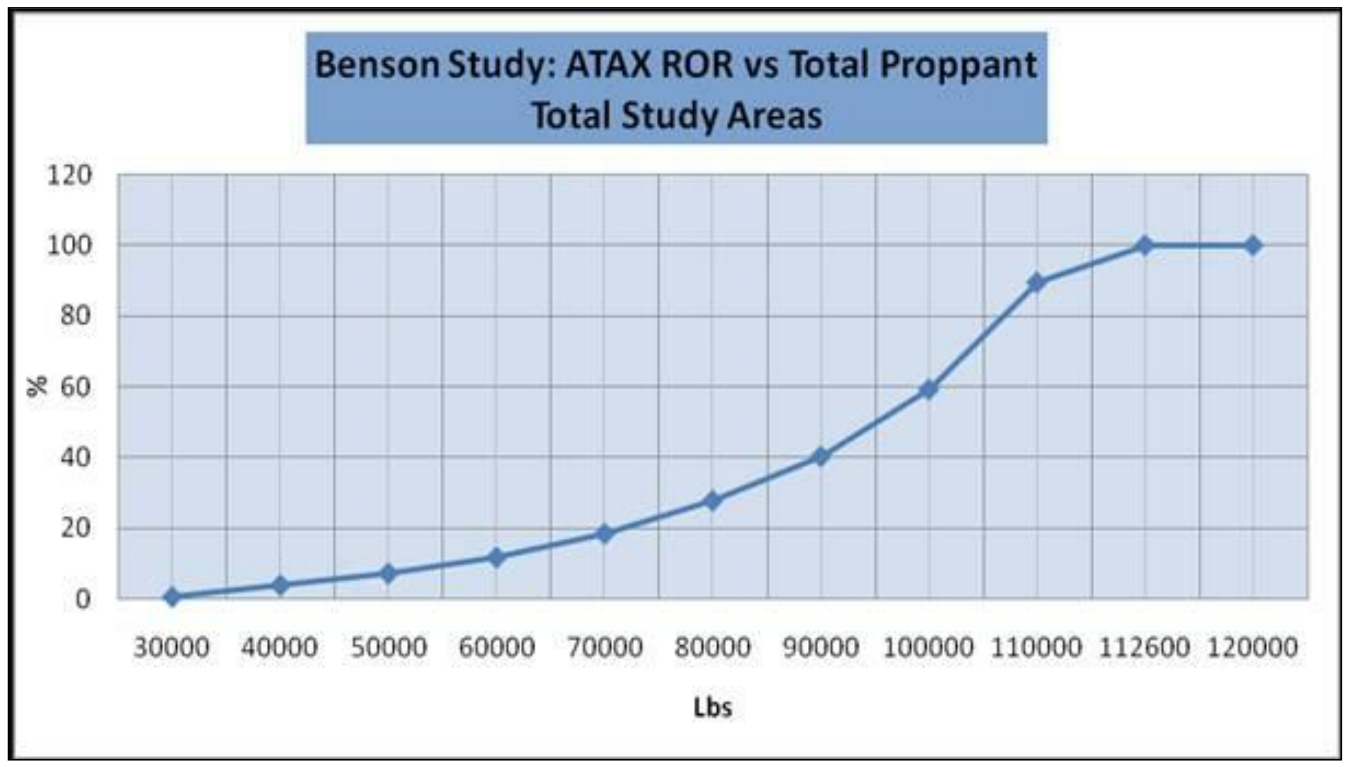

Figure 19: ATAX ROR for Total Area 


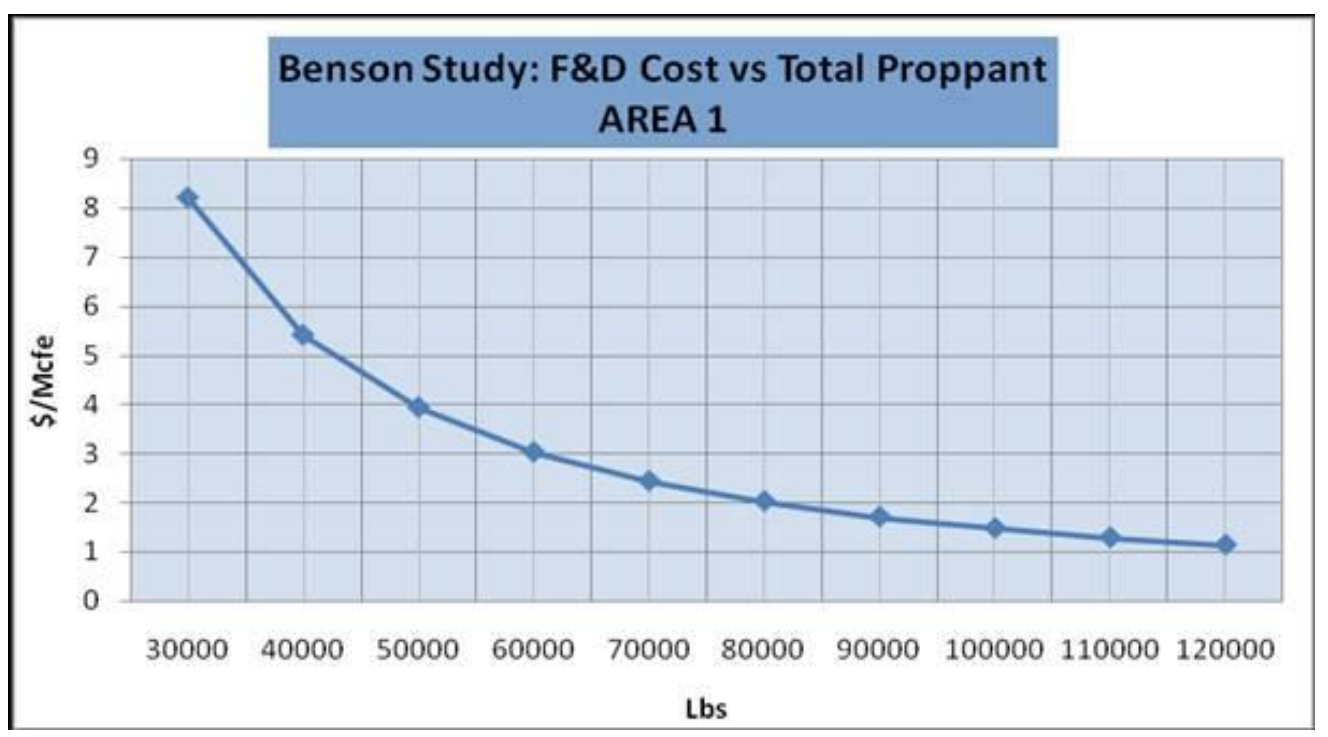

Figure 20: F\&D Costs for Area I

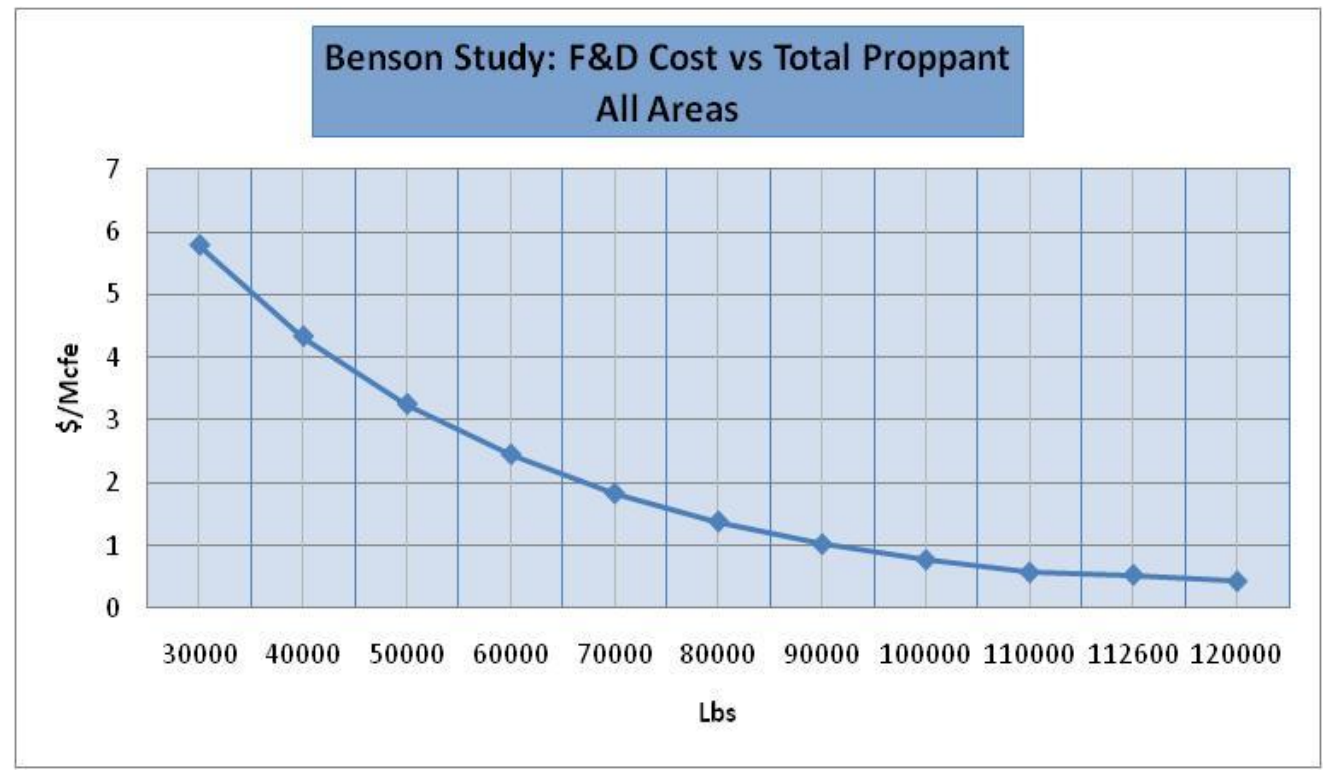

Figure 21: F\&D Costs for Total Study Area 


\begin{tabular}{|l|l|c|c|}
\hline \multicolumn{3}{|l|}{ From Trend Line I } \\
\hline Prop (lbs) & EUR (MMcf) & ATAX ROR (\%) & F\&D Cost (\$/Mcfe) \\
\hline 30000 & 45 & 0 & 8.21 \\
\hline 40000 & 69 & 2.1 & 5.41 \\
\hline 50000 & 96 & 6.3 & 3.94 \\
\hline 60000 & 126 & 10.9 & 3.03 \\
\hline 70000 & 158 & 15.7 & 2.44 \\
\hline 80000 & 193 & 21.1 & 2.03 \\
\hline 90000 & 230 & 27.6 & 1.71 \\
\hline 100000 & 269 & 33.5 & 1.48 \\
\hline 110000 & 309 & 39.9 & 1.29 \\
\hline 120000 & 352 & 47.7 & 1.14 \\
\hline
\end{tabular}

Table 8: Results of Economics for Area I

\begin{tabular}{|c|c|c|c|}
\hline \multicolumn{4}{|l|}{ Trom Trend Line } \\
\hline Prop (Lbs) & EUR (MMcf) & ATAX ROR (\%) & F\&D Cost (\$/Mcfe) \\
\hline 30000 & 64 & 0.75 & 5.78 \\
\hline 40000 & 86 & 4.1 & 4.33 \\
\hline 50000 & 116 & 7.4 & 3.25 \\
\hline 60000 & 156 & 11.9 & 2.45 \\
\hline 70000 & 211 & 18.6 & 1.83 \\
\hline 80000 & 285 & 27.9 & 1.38 \\
\hline 90000 & 384 & 40.4 & 1.02 \\
\hline 100000 & 519 & 59.3 & 0.77 \\
\hline 110000 & 700 & 89.5 & 0.57 \\
\hline 112600 & 757 & 100 & 0.53 \\
\hline 120000 & 945 & 100 & 0.43 \\
\hline
\end{tabular}

Table 9: Results of Economics for Total Study Area 


\section{Chapter 5}

\section{CONCLUSION AND RECOMMENDATIONS}

\section{Conclusion}

The following conclusions were obtained duing this study

1. No significant correlation between cumulative production (or EUR) and pay thickness was found in the study area.

2. The low formation permeability is probably the reason for the lack of correlation between EUR and pay thickness.

3. No significant correlation between cumulative gas production (or EUR) and total volume of treatment fluid injected was found in the study area.

4. Reasonable correlations between EUR (or 5-year and 10-year cumulative productions) and total proppant placed were found in all four areas studied.

5. Increasing the total proppant placed during stimulation treatments was found not only to increase EUR but also to decrease the number of wells needed to effectively drain the reservoir.

6. To expect an ATAX ROR of around $15 \%$ in area I, it would require around 70,000 Lbs of proppant to be placed in a single stage Benson completion well.

7. In the total study area, it would require around $65,000 \mathrm{lbs}$ of proppant to achieve an ATAX ROR of around $15 \%$. 


\section{Recommendations}

The Following recommendations are based on the research done and the findings from the analysis of this study.

1. Because of the small variance in the injection rate during stimulation of the sampled wells, further research could be done on a sample of wells that had a larger variance in injection rate to investigate the effects on gas production or EUR.

2. The size of proppant injected during stimulation was not very detailed in the data available in this study. Because of this more, research could be done on the size of proppant used to see if the larger proppant with greater conductivity would yield better wells.

3. The sample wells have a range of proppant place during stimulation between 30,000 Lbs and 105,000 Lbs. More research could be done to find the point of diminishing returns. It is assumed that at some point the cost and risk would outweigh the gas production gains. In this study it was not seen.

4. Because of the findings on the correlation between EUR and feet of pay in this study, more research could be done on feet of pay. 


\section{REFERENCES}

1. Veatch, R.W., Jr. and Moschividis, Z.A., "Overview of Advances Hydraulic fracturing Technology,” SPE 14085, Proceedings of 1986 SPE International Meeting

2. Aminian, K, Ameri, S., Bright, D. and Yost, A.B., II:”The Evaluation of Hydraulic Fracturing Treatments for the Big Injun Formation in West Virginia,” SPE 18540, Proceedings of 1988 SPE Eastern Regional Meeting

3. Woodrow, D.L and Sevon, W.D., "The Catskill Delta", (Special Paper / The Geological Society Of America; 201)

4. Reger, D.B. and Teets, D.D., Jr., "West Virginia Geological Survey”, (County Reports 1918, Barbour and Upshur Counties and Western Portion of Randolph County.

5. Walker, B.J. “The Atlas of Major Appalachian Gas Plays”, (West Virginia Geological and Economic Survey / Upper Devonian Bradford Sandstones and Siltstones.)

6. Howard, G.C. and C.R. Fast (editors), Hydraulic Fracturing, Monograph Vol. 2 of the Henry L. Doherty Series, Society of Petroleum Engineers New York, 1970.

7. David D. Cramer, Conoco Phillips, "Stimulating Unconventional Reservoirs: Lessons Learned, Successful Practices, Areas for Improvement”. SPE 114172 Copyright 2008, Society of Petroleum Engineers.

8. N.R. Warpinski, M.C. Vincent, C.L. Cipolla, and E.P. Lolon, "Stimulation Unconventional Reservoirs: Maximizing Network Growth While Optimizing Fracture Conductivity". JCPT October 2009, Volume 48, No 10 
9. Aminian, K, Ameri, S., Bright, D. and Yost, A.B., II:'The Evaluation of Hydraulic Fracturing Treatments for the Big Injun Formation in West Virginia,” SPE 18540, Proceedings of 1988 SPE Eastern Regional Meeting.

10. BJ Services, "Electronic Engineering Handbook”, Version 1.6 copyright 2006, (Nitrogen and Carbon Dioxide)

11. Fekete, Fast RTA ${ }^{\mathrm{TM}}$ Version 3.207 (LS Version 1.0.18.0) Copyright 2001-2009,

12. Landmark Graphics Corporation, “ARIES Fundamentals”, Copyright 2005, (Halliburton / Digital Consulting Solutions) 


\title{
THE IMPACT OF STIMULATION TREATMENT ON EUR OF UPPER DEVONIAN FORMATIONS IN THE APPALACHIAN BASIN
}

\author{
By \\ Robert H. Krcek \\ A thesis submitted in partial fulfillment of the requirements \\ for the degree of
}

MS Degree in Petroleum and Natural Gas Engineering

West Virginia University

2010

Approved by

Chairperson of Supervisory Committee

Program

Authorized

to Offer Degree

Date

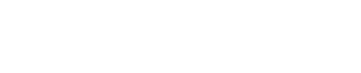

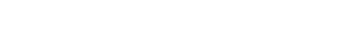

Hagenemail.wunuedu, $c=U S$
Date: 2010.04.27 13:58:49 